\title{
أنماط المناخ الأسرى وعلاقته بالانضباط المدرسي لدى طلاب المرحلة الثانوية
}

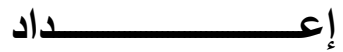 \\ د. محمد عبد الحكيم خلف \\ مدرس بقسم خدمة الفرد \\ المعهد العالي للخدمة الاجتماعية ببنها
}

$$
r+1 \mathrm{r}
$$


شهد العالم في الآونة الأخيرة تطورات وتغيرات سريعة ومتلاحقة في مختلف ميادين الحياة، وتعد هذه التغيرات بمثابة تحديات نواجه المجتمع المعاصر ، وتجعله في سباق دائم من أجل الحفاظ على هوني هويته الثقافية في مواجهة الغزو الفكري والثقافي المعاصر، وتجعله في محاولة للتوفيق بين ما هو محلي وما

هو عالمي (Douglas Kellner,2000: 305) والإنسان لا يعيش بمعزل عن الآخرين بل يعيش في محيط ينكون من عدد من العناصر المادية

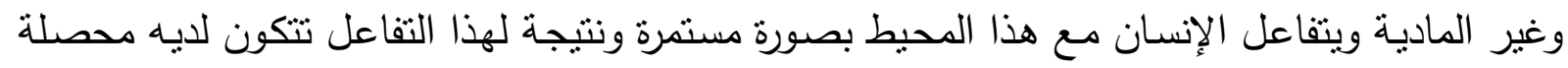
تتألف في مجملها من مجموعة من الأفكار والمشاعر والسلوكيات وتعد الأسرة هي الوسط الإنساني الأول الذي ينشأ فيه الإنسان، وتتبلور فيه شخصيته وتمثل الأسرة شبكة من العلاقات الإنسانية الاجتماعية،

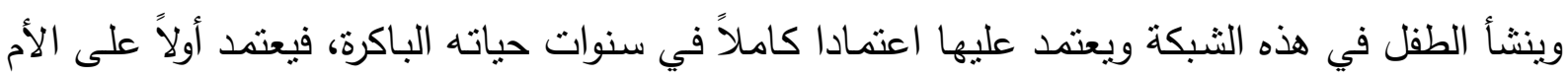

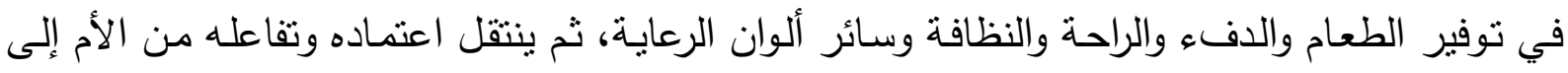

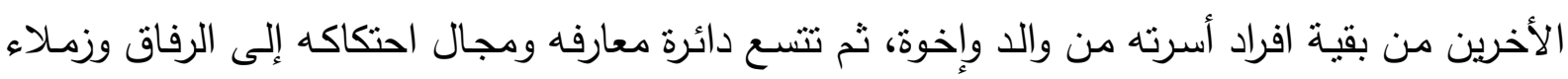

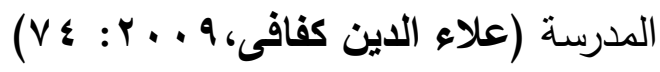

وتلعب الأسرة في هذا المجال يلعب دورًا كبيرًا، إذ إن الاهتمام بالعلاقات والتفاعلات بين أعضاء

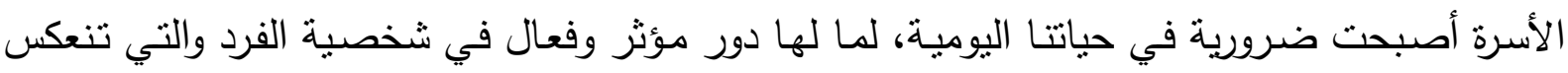

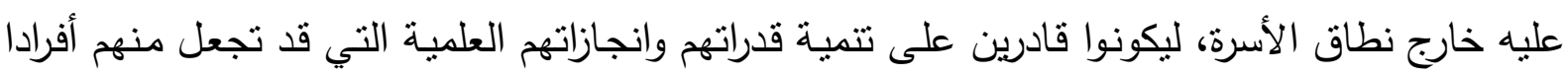

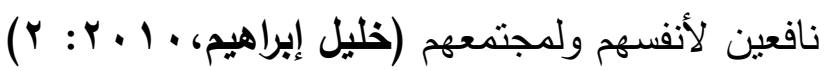

ويمثل المناخ المدرسي منظومة من القيم والمعايير والمعتقدات والمبادئ والممارسات التي تكونت

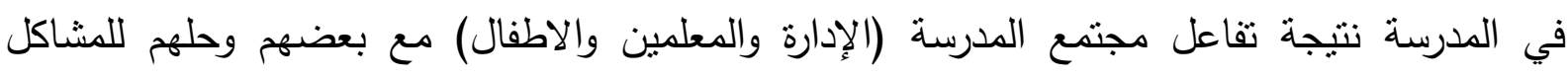
والتحديات التي تواجهرم، وتتم دراسة ثقافة الددرسة من خلا تركيز الباحثين التربويين على القيم التقافية

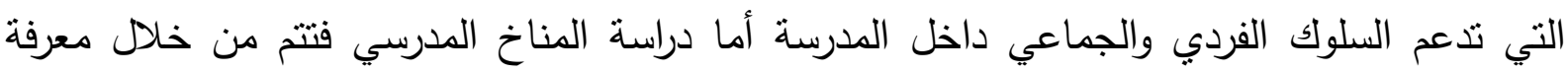

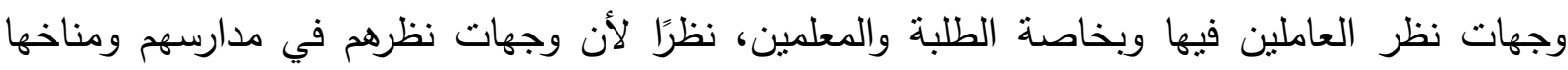

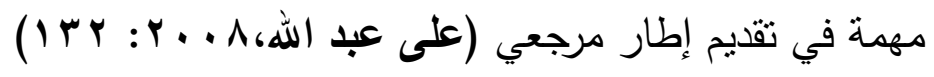

ويعد التعليم الثنانوي العام نقطة التحول الجوهري في حياة الطالب؛ لذا بستقطب جانبًا كبيرًا من الآمال

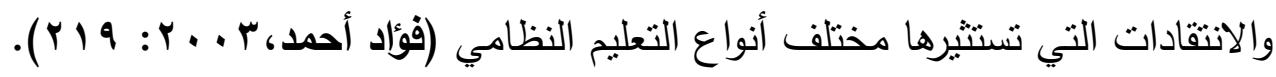
وانطلاقًا من الإيمان الراسخ بأهية المرحلة الثانوية وطلابها - باعتبارهم الطاقة المحركة والقوى

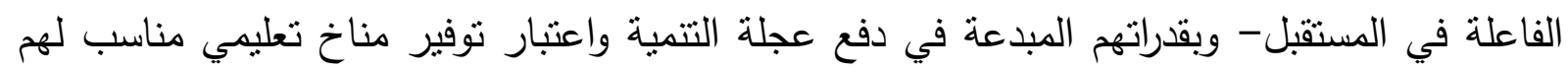

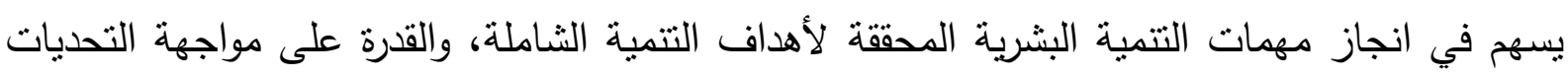

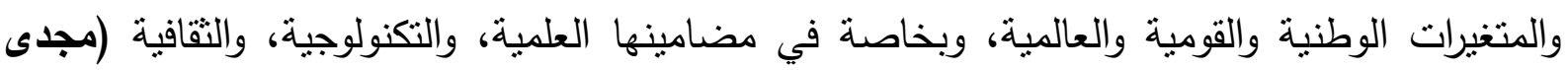


ماهر، 99 19 1 ب ) فقد بات من الضروري التصدي للمشكلات التي يحدثها هؤلاء الطلاب وتعد خروجها على النظام وإخلالاً بالانضباط المدرسي.

ويرتبط الانضباط المدرسي بمجموعة من القواعد والقوانين التي تتظم العمل داخل المدرسة وبعض هذه القواعد يتعلق بضبط سلوك المعلمين والعاملين بالمدرسة وبعضها الآخر يتعلق بضبط سلوك الطلاب بما يمكن أن يسهم في تحقيق الأهداف المرجوة من العملية التعليمية، غير أنه أثناء التفاعل الاجتماعي بين الطلاب بعضهم بعضا وبينهم وبين معلميهم تبرز مشكلات قد تعوق سير العملية التعليمية وتتعارض مع هذه الأهداف وتلاك القواعد والقوانين، وتوصف هذه المشكلات بأنها إخلال

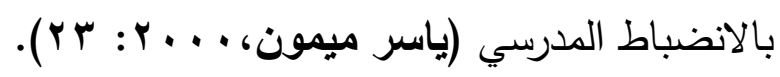

ومن الملاحظ أن طلاب وطالبات المرحلة الثانوية وخاصة العامة يعيشون اليوم في عالم مضطرب، تضاربت فيه القيم المادية، والأخلاقية، والاجتماعية، فضلاً عن المرحلة العمرية الحرجة التي Mike ) يمرون بها والتي تتسم باللجوء كثيرًا لإبراز القوة العضلية فيما يعرف بأزمة القوة العضلية Calver \& Jenny Henderson,1998: 70 العنف أو تعاطي المخدرات أو إثعال الحرائق في الممتلكات، ولذلك قد أوصت الرابطة القومية لمجالس إدارات المدارس بالولايات المتحدة الأمريكية بضرورة دعم سياسات الأمن والأمان بالمدارس، وتدريب هيئة المدرسة على الاستعداد للطوارئ والأزمات (عدنان محمد، ه . . Y ب r I ).

والواقع أن خروج الطلاب على قواعد النظام المدرسي وضعف الانضباط ظاهرة خطيرة تصدر عن أعداد كبيرة في الوقت الحاضر، وهذا ما نتير إليه العديد من الدراسات، فلقد أكدت إحدى الدراسات أن مشكلة ضعف الانضباط هي مشكلة شائعة واسعة الانتشار في المدارس في جميع أنحاء العالم، ولها Karin ) نتائج سلبية بالنسبة للمناخ المدرسي العام، وتؤدي إلى إعاقة العملية التعليمية في المدرسة Natvig,2001)، ووجدت إحدى الدراسات أن نسبة كبيرة من الطلاب لا يلتزمون في سلوكياتهم بالتقاليد والآداب الاجتماعية، ولا يلتزمون كثيرًا بتعاليم المدرسة، سواء داخل الفصول أو خارجها وإن ذلك يعد من ون أبرز مشكلات التعليم في مصر (يوسف عبد المعطي، و 9 1 ). فقد أشارت العديا من الدراسات الحديثة لكلاً من : (Agent Memoir,2000) دراسة (عادل

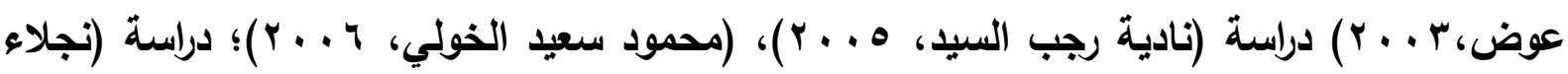

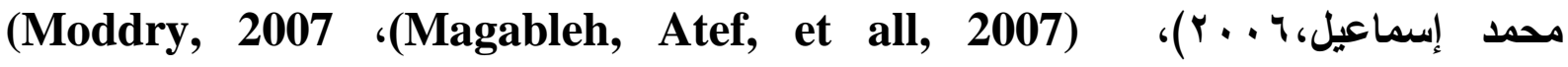

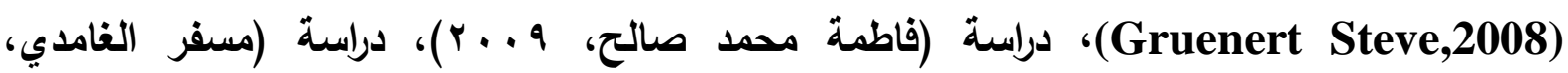

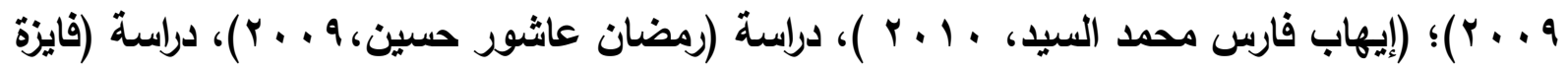

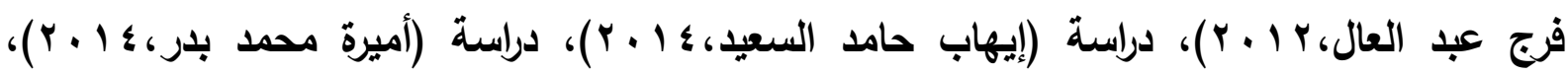

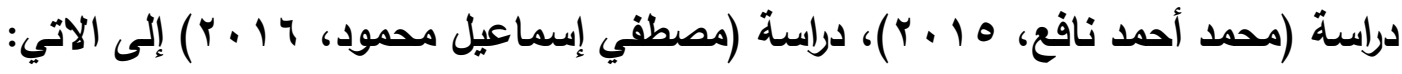


1- أن أكثر مظـاهر عدم الانضباط السلوكي ناتجـة عن الفروق في أساليب المعاملـة الوالديـة السوية

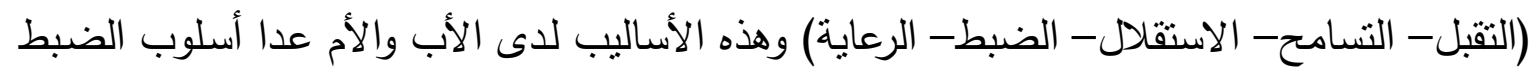

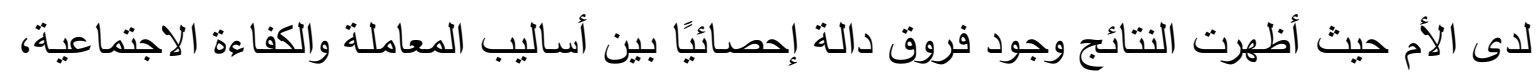

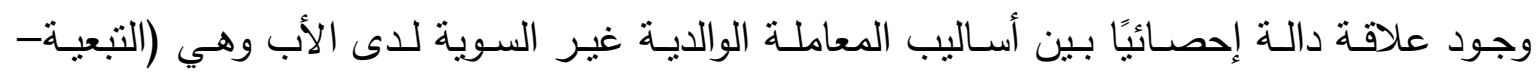

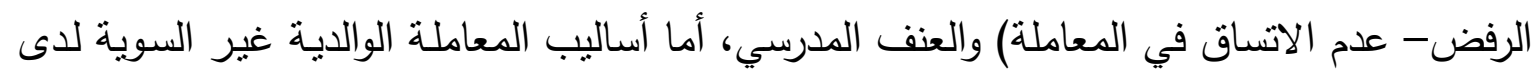

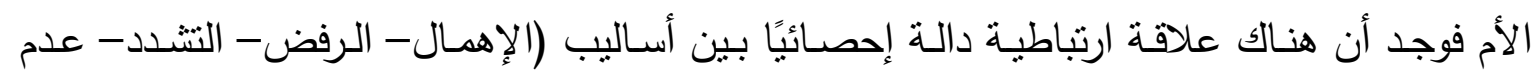

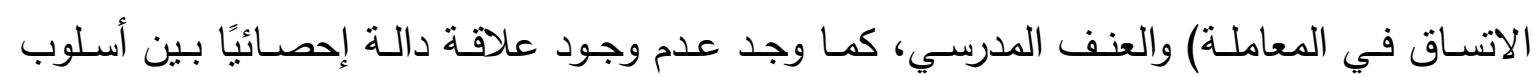

$$
\text { (التبعية) لاى الأم والعنف المدرسي. }
$$

r- أن معدلات انتشـار ظاهرة عدم الانضباط والعنف مرتفعة كما أن العوامل المدرسية مثل مشـاركة

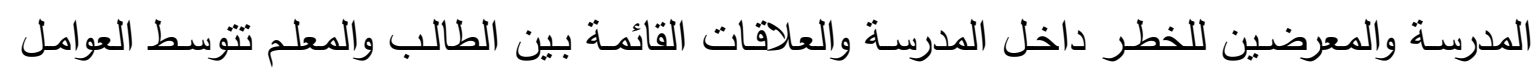

$$
\text { الثخصية والأسرية في عدم الانضباط. }
$$

r- ينبغي من مؤسسات المجتمع التربوية والتعليمية والإعلامية والإسهام في بناء الأسرة والتخطيط لفتح

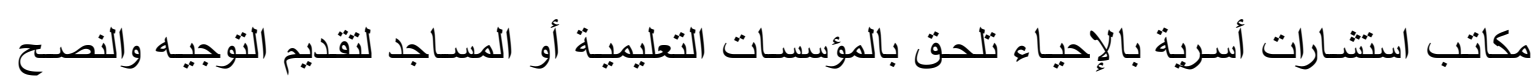

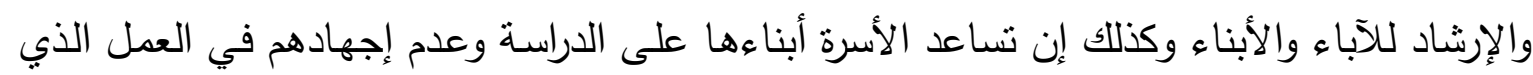

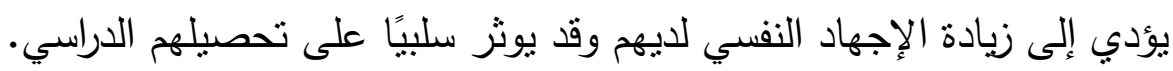

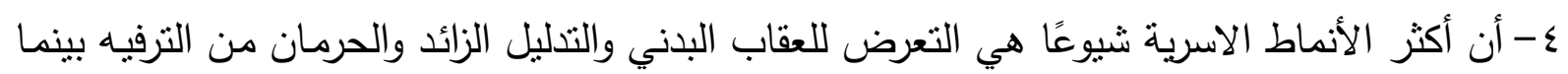

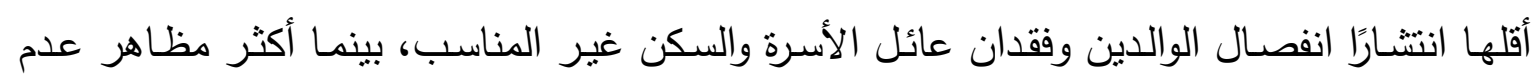

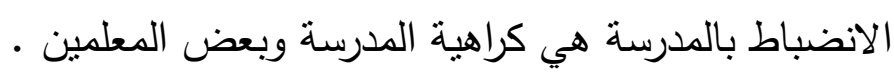
ه- أثنارت النتائج إلى أن الاستراتيجيات المتبعة من قبل المبل المعلم في ضبط الفيط الفصل تتقسم إلى إجراءات

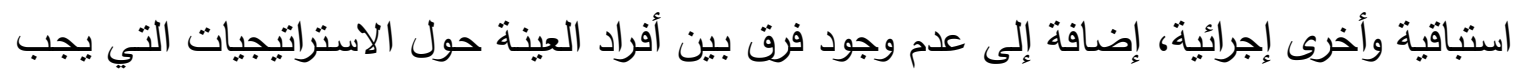

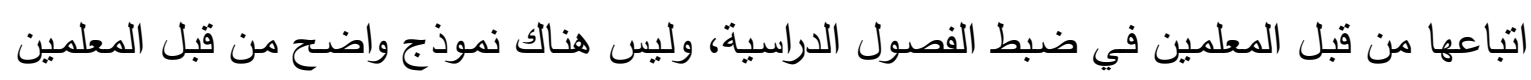
في الضبط الدرسبي. צ- العلاقة الدافئة بين الفرد وإخوته والتعبير العاطفي واتفاق الوالدين في التربية أسهمت بشكل كبير في تكيف الطالب بعد ستة أثهر من الدراسة حسب ما ذكرته الأمهات والمعلمون.

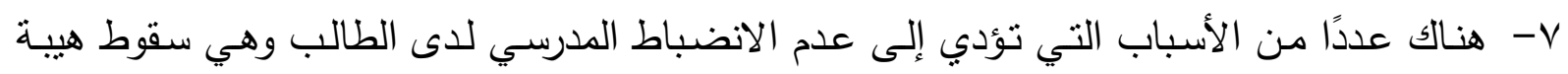
المعلم بسبب الدروس الخصوصية، ونظرة الطلاب المتدنية نحو فرص مستقبلهم الدراسي الذي يترتب

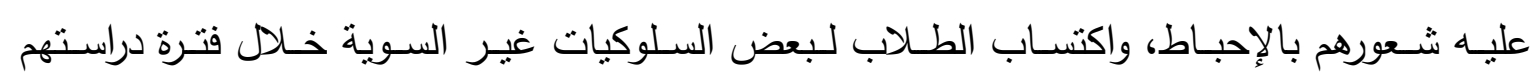
بالمدرسة والتي نرجع إلى المناخ الددرسي غير الصحي.

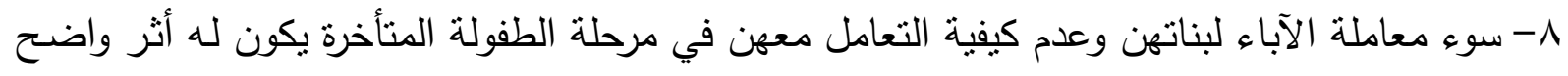

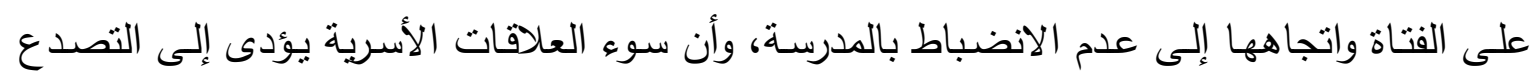


الأسرى حيث أن الإناث أكثر نأثرًا بالخلافات والعلاقات الأسرية غير السوية مما يؤدى إلى عدم الانضباط.

9- بعض المشكلات منواجدة بدرجة منوسطة، ومنها: سرحان بعض الطلاب أثناء الحصة، التقصير في

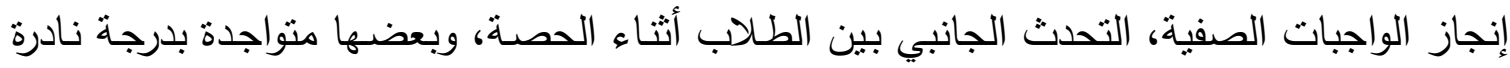

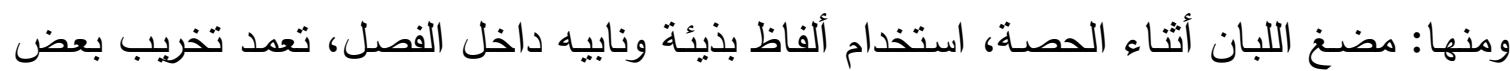
الطلاب ممتلكات زملائهم داخل الفصل.

• ا- الافراد الذين يتمتعون بمناخ أسري جيد يتمتعون بصحة نفسية وانضباط سلوكي جيدة كما بينت

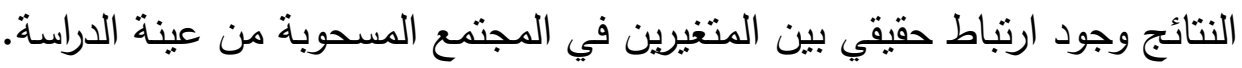

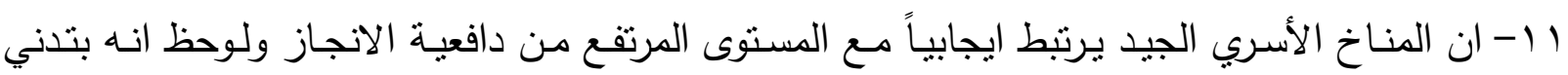

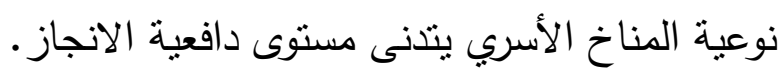
r ا-توجد علاقة ارتباطبة موجبة بين المستوى التعليمي والانضباط الددرسي لكل من الوالدين بالأسرة وكل

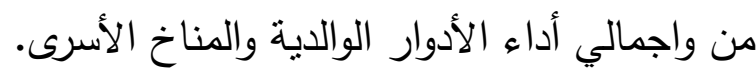

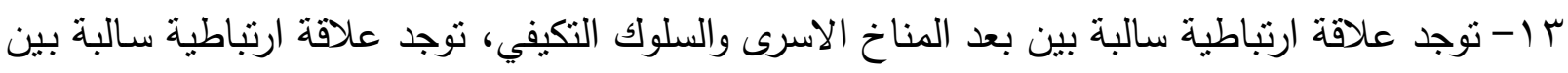

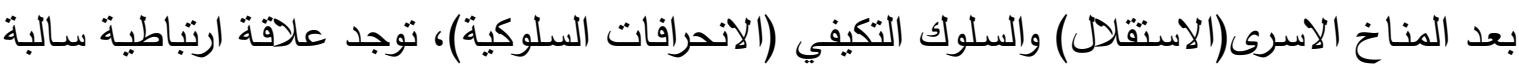
بين بعد المناخ الاسرى (التوجيه نحو التحصيل والانجاز).

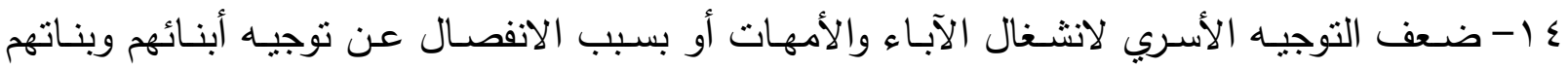
وإكسابهم الأخلاق والعادات الحميدة. 10 - المستوى الاجتمـاعي والاقتصـادي فالفقر والجهل لهما تأنثير سلبي على انضـباط الطفل وبالتـالي الانضباط المدرسي. 17 تحقيق انضباط أعلى من غيره. V ا أثر المؤسسات الاجتماعية كالمسجد والمؤسسات الأمنية فكلما كان أداء مهماتها في توجيه المجتمع فاعلة ساعد ذللك كثيراً على الانضباط. 1 1- الانضباط مهم للجانب الاجتماعي بين الطلاب ومعلميهم وإدارة المدرسـة؛ مما بسهم في خلق بيئة مشجعة على التعلم. 9 1- الانضباط يعلم أهمية التتظيم والتخطيط لإنجاز أي عمل وبدونه تعم الفوضى والعشوائية في العمل مما ينعكس على أداء الطلاب مستقبلاً. • r- الانضباط يؤدي إلى تحقيق مجتمع ذب سلوك حضاري في تعامله مع الآخرين، وفي التزامه بالأنظمة والقوانين السائدة في المجتمع. 
وتلعب أنماط المناخ الأسري دور مهم في نتكيل سلوك هؤلاء الطلاب وتؤثر على سلوكهم الدراسي سواء بشكل إيجابي أو بشكل سلبي، وذلك يتوقف على نمط التعامل السائد داخل الأسرة. وقد ذكر "كفافي" أن الصحة النفسية للفرد ونجاحه في أداء وظائفه المختلفة في الحياة يرتبط إلى حد كبير بالمتغيرات المنصلة بهذا التظيم (النسق) الأسري مثل نوع المناخ الذي كان سائدًا في الأسرة، وطبيعة المعاملة الوالدية التي يتلقاها الطفل من والديه، ومدى سلامة العلاقات التي كانت بين الوالدين

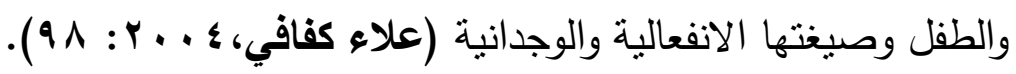

لذا تتأثز انفعالات الأبناء عند التعرض للمواقف الأسرية الضاغطة، ومن أهم التأثيرات الانفعالية:

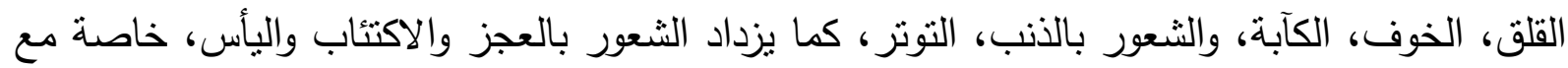

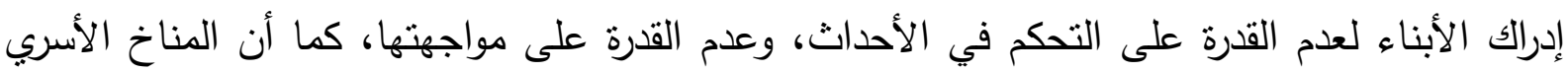

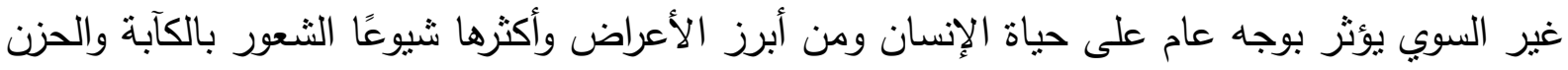

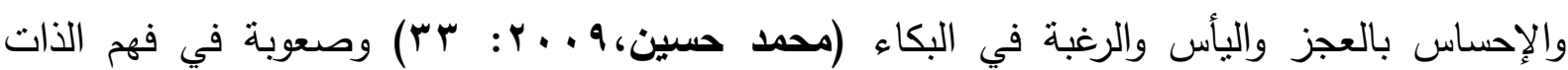
والآخرين، التسرع والتهور والغضب، هبوط الأداء في العمل، البكاء المتكرر، القلق المفرط، ويصبح الفرد عرضه للحوادث، وتزداد مشكلات الكلام، ويقل الحماس، وتتخفض الطاقة والدافعية، وينخفض بذل الجها

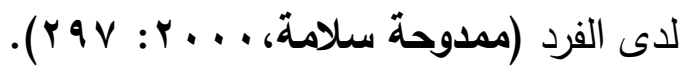

والمنــاخ الأسـرى والمدرسـي الـذي يسـوده الانسـجام والحـب والفهـم والتقـة والاحتـرام المتبــادل

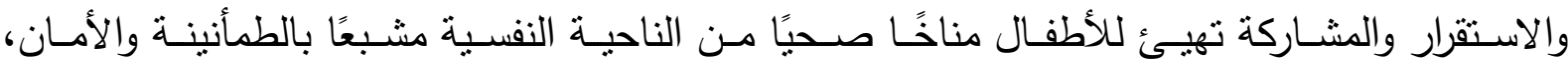

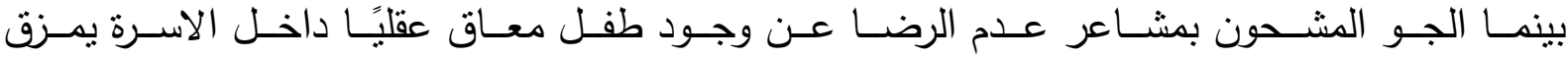

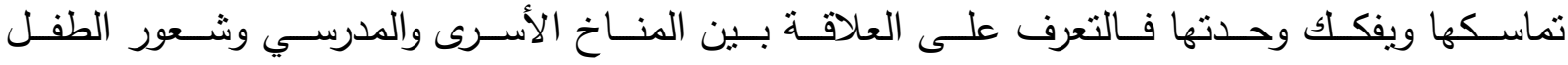
بجودة الحيـاة هـام جـًا للوقوف على المشـكلة والعهل على حلهـا بمختلف الطـرق العمليـة التزبويـة

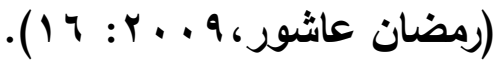

وفي ضوء ما سبق؛ تتبلور مشكلة البحث في تساؤل رئيسي مؤداه: ما العلاقة بين أنماط

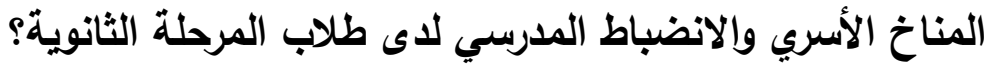

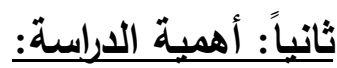

إن دراسة أثر أنماط المناخ الأسري والانضباط المدرسي لدى طلاب المرحلة الثانويـة لـه أهمية بالغة، ويتضح ذلك من خلال ما يلي:

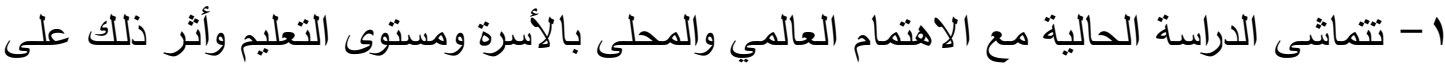

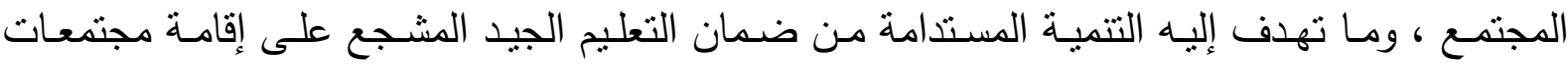

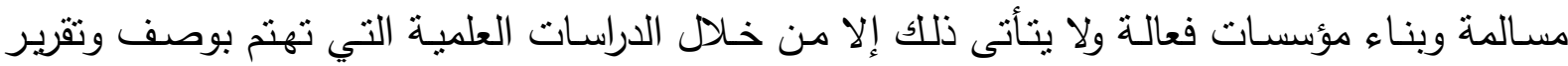

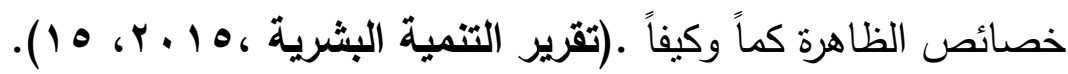


ץ- كما تتبع أهمية الدراسة من أهمية الانضباط الددرسي فهو شرط أساسي للتعليم والتعلم؛ لما

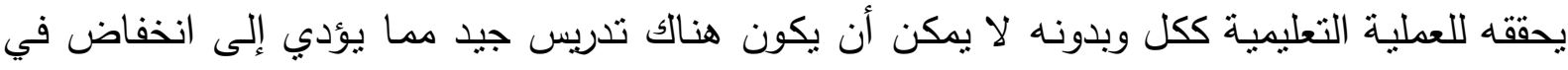

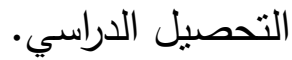
r- عدم الانضباط داخل المدرسـة بعكس بصورة أو بأخرى الأنماط الاسرية وتأثثير ذلك على لـى

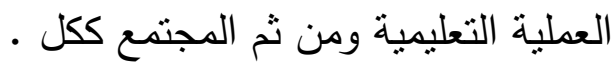
ع - يستقيد من هذه الدراسة كل القائمين على العملية التربوية والتعليمية وخاصة القائمين بعملية التعليم والتدريس بمختلف المدارس . ثالثاً: أهداف الدراسة: إن هذه الدراسة تهدف بشكل أساسي ومباشر إلى دراسة العلاقة بين أنماط المناخ الأسري والانضباط المدرسي لاى طلاب المرحلة الثانوية، من خلال:

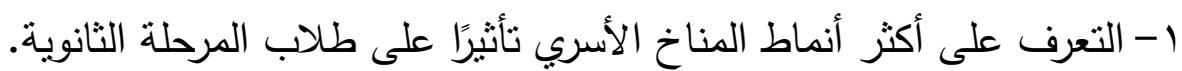

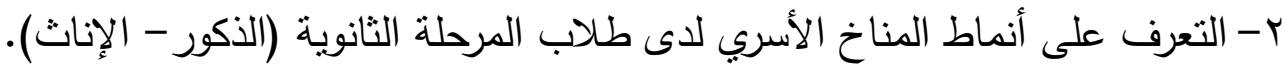
r- التعرف على مستوى الانضباط المدرسي لاى طلاب المرحلة الثانوية (الذكور - الإناث). ع- تحديد طبيعة العلاقة بين أنماط المناخ الأسري والانضباط المدرسي لدى طلاب المرحلة الثانوية.

\section{لإيعاً: فروض الدراسة:}

1- وجود فروق دالة إحصائيًا بين الذكور والإناث فيما يتعلق بأنماط المناخ الأسري لدى طلاب المرحلة

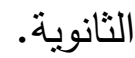

r- وجود فروق دالة إحصائًاً بين الذكور والإناث فيما يتعلق بالانضباط المدرسي لدى طلاب المرحلة

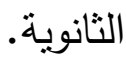

r- وجود علاقة دالة إحصائيًا بين أنماط المناخ الأسري والانضباط المدرسي لدى طلاب المرحلة الثانوية.

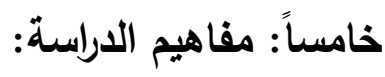

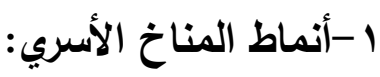

يعـرف المنــاخ الأســري بأنــهـه " الطــابع العـام للحيـاة الأسـرية مـن حيـث تــوافر الآمـال

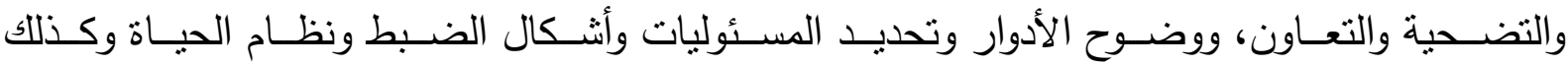

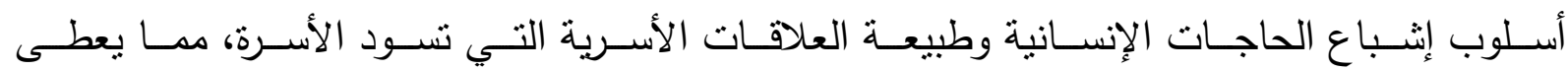

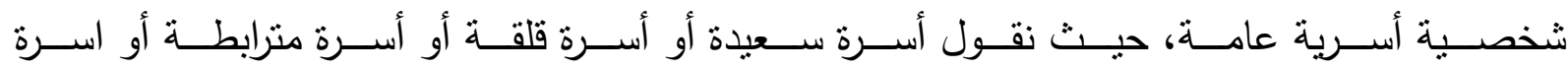

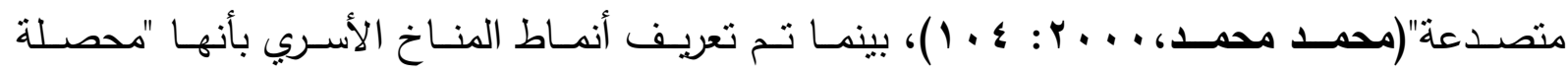

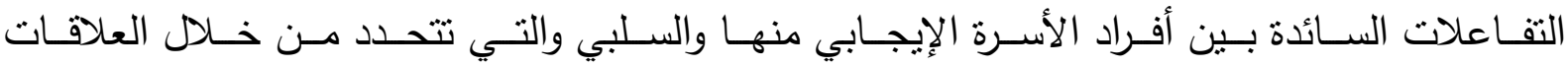




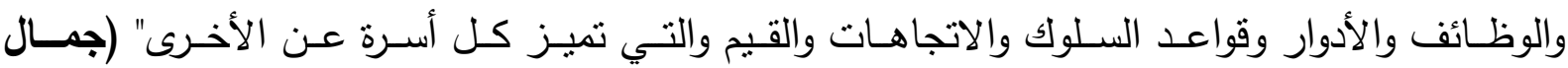

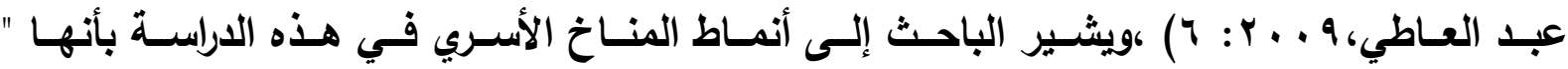

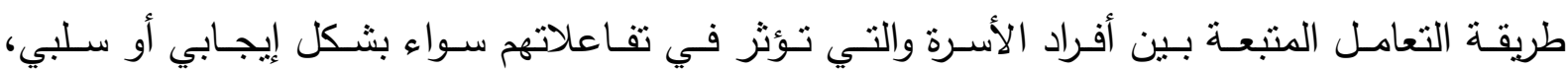

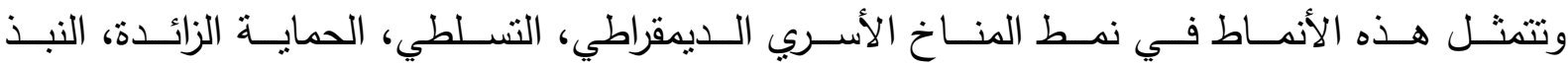

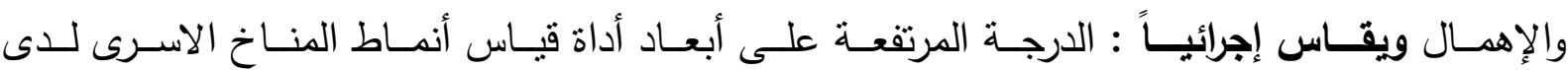
طلاب المرحلة الثانوية موضوع الدراسة الراهنة.

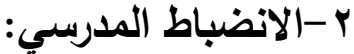

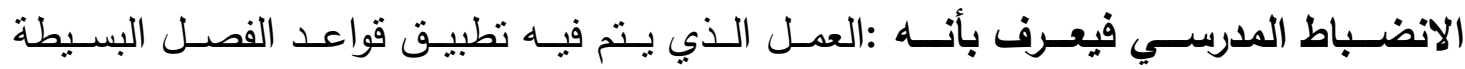

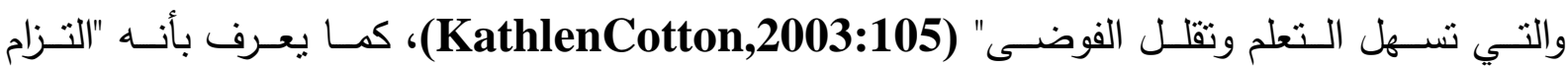

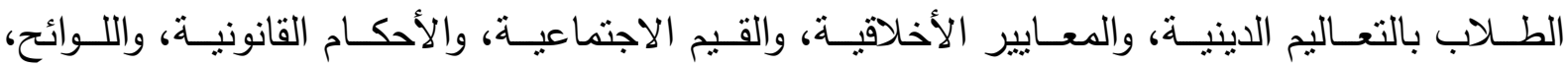

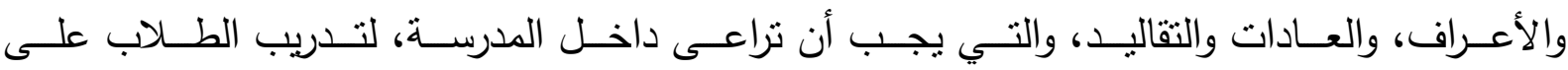

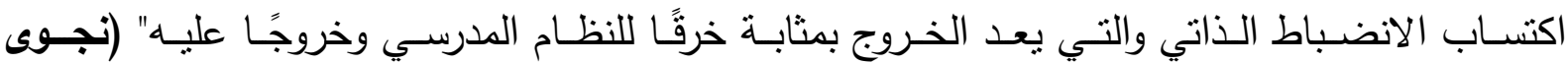

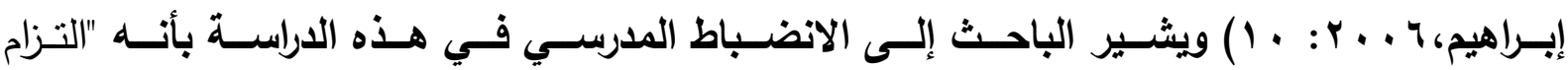

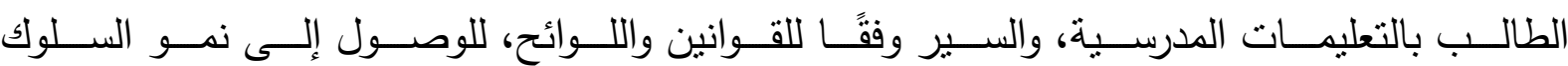

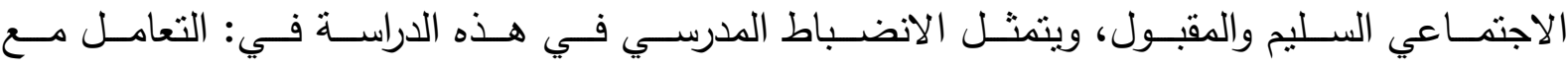

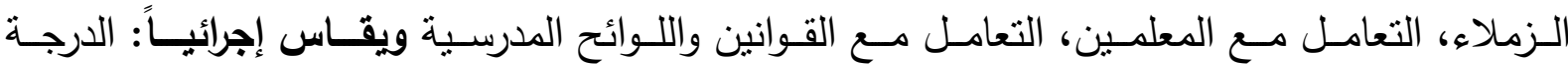

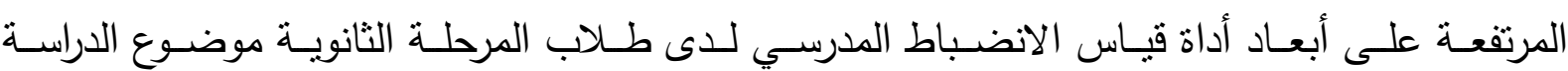

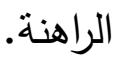

سادساً: الإجراءات المنهجية للاراسة: نوع الاراسة: تتتمي هذه الدراسة إلى نمط الدراسات الوصفية التحليلية لتحديد العلاقة بين متغيرين وهما: انماط المناخ الاسرى، والانضباط الدرسي. لاعني. منهج الدراسـة: اعتمد الباحث على منهج المستح الاجتماعي بطريقة العينة وذلك بهدف الحصول على سلى مجموعة من البيانات وتأويلها من حيث موضوعها لتوضيح العلاقة بين متغيرات الدراسة.

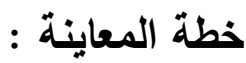
أ- إطـار المعاينـة : بلـغ عدد الطـلاب "بمدرسـة شبرابخوم الثانويـة" التابعـة لإدارة قويسنا التعليميـة

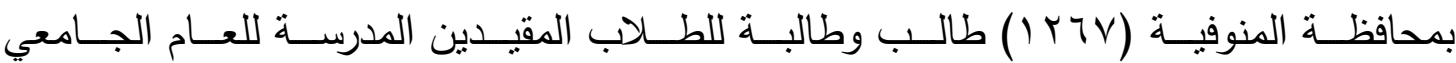

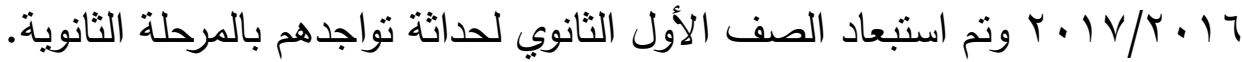




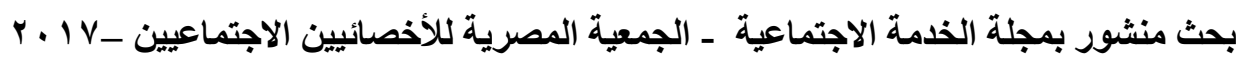

ب-نوع العينة وحجمها : تم تطبيق معادلة تحديد حجم العينة لـ "ستيفن ثامبسون *" أصبح عددهم

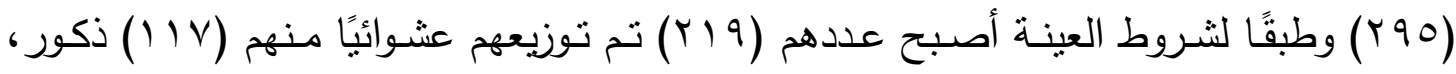

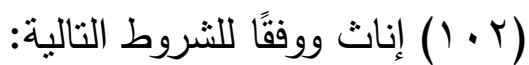

$n=\frac{N \times p(1-p)}{\left.\left.\llbracket N-1 \times\left(d^{2} \div z^{2}\right)\right]+p(1-p)\right]}$ معادلة ستيفن ثامبسون - - أن يكون الأب والأم على قيد الحياة. - أن يكون الأب والأم غير منفصلين. - أن يكون لدى الطالب/الطالبة موقف بسجل الأخصائي الاجتماعي وسلوكيات دالة على عدم الانضباط المدرسي. - - أن يوافق الطلاب على التعاون مع الباحث. ج-وحدة المعاينة : الطلاب المقيدين بالمدرسة من طلاب المرحلة التانوية . أدوات الارراسة: اعتمد الباحث على مقياسين لجمع البيانات، ودراسة وتحليل موضوع الدراسة: أ- مقياس أنماط المناخ الأسري (إعداد جمال عبد العاطي، 9 . . r). ب-مقياس الانضباط المدرسي (إعداد الباحث). وفيما يلي توضيح بناء الأدوات التي تم استخدامها في الاراسة: أ- مقياس أنماط المناخ الأسري: وفيما يلي وصف الميحي لهياس: الجزء الأول: يثمل البيانات الثخصية المتعلقة (بالعمر، عدد الأخوة، الجنس) وجعل الاسم اختياريًا، والتعليمات الخاصة بأسلوب الاستجابة وما يراعيه المبحوث في استجابته. الجزء الثاني: ويشتمل على (عا) عبارة موزعة على أربعة أنماط هي: (الديمقراطي، التسلطي، النبذ والإهمال، الحماية الزائدة)، وتم توزيع العبارات بشكل عشوائي؛ فتم ترتيب العبارة الأولى من هن المناخ الديمقراطي، ثم العبارة الأولى من المناخ التسلطي، العبارة الأولى من المناخ النابذ، ثم العبارة الأولى من المناخ الحماية الزائدة، ثم العبارة الثانية من كل نمط... وهكذا. - تم تحديد أسلوب الاستجابة؛ حيث كانت الاستجابات (نعم- أحيانًا - لا) وأن تتم الاستجابة في نفس ورقة العبارات لعدم التشتت أو تعرضهم للخطأ. الصدق والثبات لمقياس أنماط المناخ الأسري في الدراسة الحالية: أ- الصدق: اعتمد الباحث على نوعين من الصدق وهما: 
ا. صدق المحكمين: وهو بتضمن نسب اتفاق المحكمين على فقرات المقياس، حيث تم عرض مقياس أنماط المناخ الأسري على عدد من أساتذة علم الاجتماع، والخدمة الاجتماعية، وعلم النفس،

$$
\text { والممارسة الميدانية على أن يتم التحكيم في ضوء: }
$$

ا ا. مدى ارتباط العبارة بكل محور من محاور الدراسة.

$$
\text { r. r. من حيث صياغة العبارة. }
$$

وبناءً على ذلك فقد تم تعديل الأبعاد العامـة للمقياس، وقد تم تعديل بعض العبارات، وحذف العبارات التي تقل نسبة الاتفاق عليها عن 0^\%؛ وقد تم حساب نسبة الاتفاق وفقًا لمعادلة (جتمان)

$$
\begin{aligned}
& \text { عدد مر ات الاتفاق }
\end{aligned}
$$

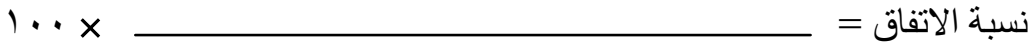

$$
\begin{aligned}
& \text { عدد مرات الاتفاق + عدد مر ات الاختلاف }
\end{aligned}
$$

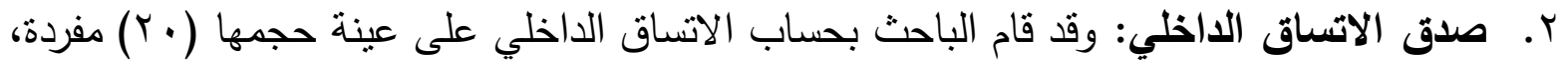
وذلك لحساب معاملات الارتباط بين كل فقرة والدرجة الكلية لمجالها، وسنتاول كل مجال على حدة،

\begin{tabular}{|c|c|c|c|c|c|c|c|}
\hline الارتباط & رقب & الارتباط & رقم العبارة & الارتباط & رقم العبارة & الارتباط & رقم العبارة \\
\hline $.70 r$ & $\varepsilon$ &..$\leqslant 01$ & r &.$V Y_{I}$ & r &. .791 & 1 \\
\hline. $.7 V$ & $\Lambda$ &.$V r q$ & V &. $.00 \mathrm{~V}$ & 7 &.$V V$. & 0 \\
\hline . .vrq & Ir &. .01 . & 11 &. $.7 \Lambda$. & 1. &.$\leqslant 07$ & 9 \\
\hline..$\Lambda .0$ & 17 &.$V T r$ & 10 &. .799 & $1 \varepsilon$ & .VTr & $1 \pi$ \\
\hline. $.70 \mathrm{r}$ & $r$. & $.01 \pi$ & 19 &..$V V 1$ & 11 &. $.7 \wedge \varepsilon$ & IV \\
\hline$. . \Sigma V \mid$ & $r \varepsilon$ & $\cdot v \cdot v$ & Tr &. .01. & Tr & . . Trt & $r_{1}$ \\
\hline.$V M Y$ & rᄉ & .710 & TV & .VAr & rT &. $.0 \wedge \mathrm{V}$ & ro \\
\hline$. v \leqslant q$ & rT &.$V Y$. & ו & צTד. & r. &.$\wedge 1$. & rq \\
\hline.$v V$ & qu & .001 & ro &.$\wedge r q$ & r & .VAr & سب \\
\hline . .VYI & $\varepsilon$. & $\cdot . \leqslant \wedge \vee$ & pq &. .019 & ऍᄉ &..$\vee \vee \wedge$ & rv \\
\hline..$V V V$ & $\varepsilon \varepsilon$ &..$\leqslant q 4$ & $\varepsilon r$ & $.7 T 0$ & $\varepsilon r$ & $. \wedge 1 \leq$ & $\leqslant 1$ \\
\hline
\end{tabular}

$$
\text { كما هو موضح في الجداول التالية: }
$$

$$
\text { جدول رقم (1) يوضح }
$$

معاملات الارتباط بين درجة العبارات ودرجة البعد الأي تتنمي إليه 


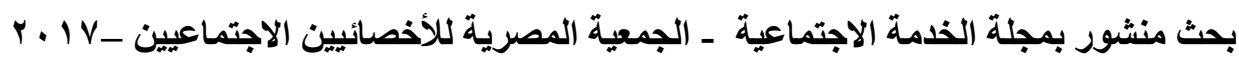

\begin{tabular}{|c|c|c|c|c|c|c|c|}
\hline.$\leqslant \vee \vee q$ & $\varepsilon \wedge$ & . & $\varepsilon V$ & $.7 V$. & $\leqslant\rceil$ & .001 & $\leqslant 0$ \\
\hline.$v 19$ & or &.$v 1$. & 01 &. .011 & 0. & $\cdot . \Lambda \cdot \varepsilon$ & $\leqslant 9$ \\
\hline .017 & 07 & 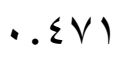 & 00 &.$\leqslant \vee \wedge$ & $0 \leqslant$ & $.7 \leq \wedge$ & r \\
\hline .7 .7 & 7. & $\cdot .7 \cdot 1$ & 09 & $.0 . r$ & $0 \wedge$ & $.70 \mathrm{~V}$ & OV \\
\hline$\cdot . \leqslant O V$ & $7 \varepsilon$ & . & rד & .711 & $7 r$ & $\cdot . \Sigma V Y$ & 71 \\
\hline
\end{tabular}

قيمة (r) الجدولية عذد مستوى دلالة (ه . . ) ودرجة حرية (1 ا) والتي تساوي (؛ ؛ ؛. .)

يتبين من الجدول السابق والخاص بمعامالت الارتباط بين كل فقرة من فقرات محاور أنماط

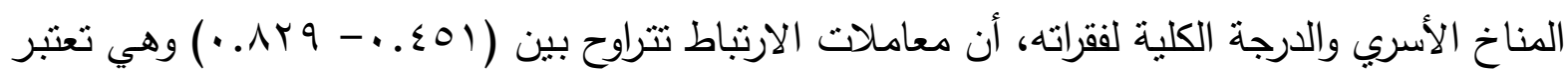
دالة عند مستوى دلالة (1 . . ·)، وهذا يعطي دلالة على ارتفاع معامالت الاتساق الداخلي، كما يشير إلى

مؤشرات صدق مرتفعة وكافية يمكن الوثوق بها في تطبيق الدراسة الحالية.

جدول (ץ) يوضح معاملات الارتباط بين درجة البعد والدرجة الكلية لمقياس أنماط المناخ الأسري

\begin{tabular}{|c|c|c|c|}
\hline مستوي الالالة & معامل الارتباط & الأنماط & م \\
\hline$\cdot . \cdot 1$ & .710 & الديمقراطي & 1 \\
\hline$\cdot .1$ &.$\vee \vee T$ & التسلطي & r \\
\hline$\cdots 1$ &. .711 & النبذ والإهمال & r \\
\hline. .1 & $.0 . r$ & الحماية الزائدة & $\varepsilon$ \\
\hline
\end{tabular}

قيمة (r) الجدولية عند مستوى دلالة (ه . . ) ودرجة حرية (1) والثي تساوي (؛ ؛ ؛ . .)

يتضح من خلال الجدول السابق أن أنماط المناخ الأسري لدى طلاب المرحلة الثانوية لها دلالة

إحصائية عند مستوى ( ( . . )، وهذا يعطي دلالة على ارتفاع معاملات الاتساق الداخلي، كما يشير إلى

مؤشرات صدق مرتفعة وكافية يمكن الوثوق بها في تطبيق الدراسة الحالية.

ب-الثبات: قام الباحث باستخدام طريقتين للتأكد من ثبات المقياس وهي:

ا. إعادة تطبيق المقياس: قام الباحث بحساب معامل ثبات المقياس، باستخدام طريقة (إعادة الاختبار

Test-Retest تطبيقها على نفس العينة بعد فاصل زمني (0 1) يومًا أي بواقع أسبوعين بين التطبيق الأول والثاني، ثم قام الباحث بحساب معاملات الارتباط بين درجات الحالات في التطبيقين الأول والثاني باستخدام معامـل ارتبـاط بيرسـون، فكـان مقداره (VAV . . . ) وهو معامـل مرتفع القيمـة دال عند مسـتوى دلالـة (0 . . ) مما يدل على أن مقياس أنماط المناخ الأسري لاى طلاب المرحلة الثانوية على درجة عالية 
r. طريقـة ألفا كرونبـاخ: قام الباحث بقياس ثبات مقياس أنماط المناخ الأسري لدى طلاب المرحلة

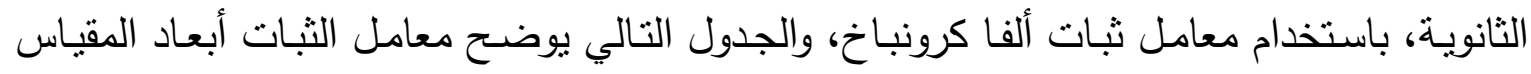

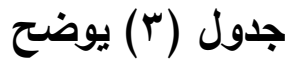

معامل ثبات ألفا كرونباخ لأبعاد مقياس أنماط المناخ الأسري لاى طلاب المرحلة الثانوية

\begin{tabular}{|c|c|c|}
\hline معامل الثبات & الأنماط & الرقم \\
\hline תז.. & الديمقراطي & 1 \\
\hline$\cdot v \cdot 1$ & التسلطي & r \\
\hline. $.70 \mathrm{~V}$ & النبذ والإهمال & $r$ \\
\hline דצטV. & الحماية الزائدة & $\varepsilon$ \\
\hline 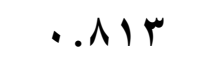 & \multicolumn{2}{|c|}{ الثبات الكلي } \\
\hline
\end{tabular}

يوضح الجدول السابق أن مقياس أنماط المناخ الأسري لاى طلاب المرحلة الثانوية يتمتع بثبات

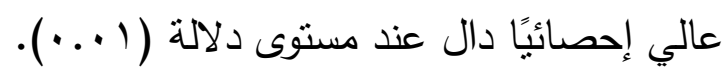
ب-مقياس الانضباط المدرسي: وقد قام الباحث عند تصميم المقياس بالاطلاع على الدراسات والبحوث

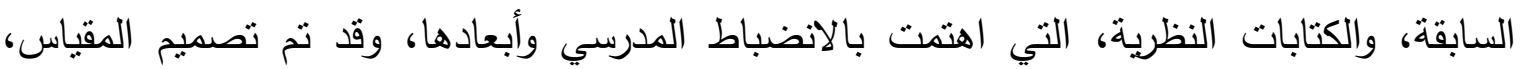

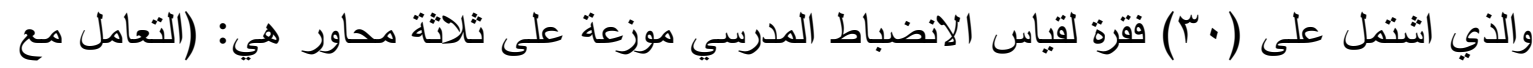
الزملاء، التعامل مع المعلمين، الالتزام بالقواعد والقوانين المدرسية). وقا راعى الباحث في تصميم المقياس ما يأتي: أ-تحديد نوع البيانات الواجب الحصول عليها. ب-وضع العبارات التي نرتبط ارتباطًا وثنيقًا بهدف الدراسة.

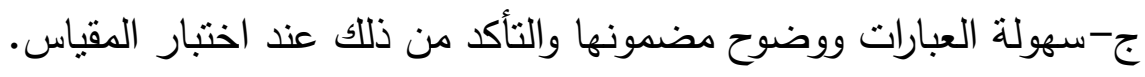
د- نَّأْسُبُ العبارات مع المستوبي التعليمي والثقافي لطلاب المرحلة الثانوية.

\section{الصدق والثبات لمقياس الانضباط المدرسي:}

أ- الصدق: اعتمد الباحث على نوعين من الصدق وهما:

1. صدق المحكمين: وهو يتضمن نسب اتفاق المحكمين على فقرات المقياس، حيث تم عرض مقياس الانضباط المدرسي لطلاب المرحلة الثانوية على عدد من أساتذة علم الاجتماع، والخدمة الاجتماعية،

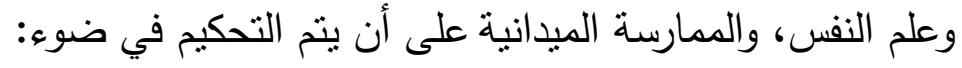

ا ـ. مدى ارتباط العبارة بكل محور من محاور الدراسة.

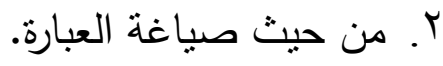

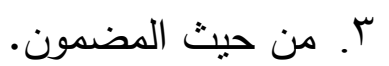


وبناءً على ذلك فقد تم تعديل الأبعاد العامـة للمقياس، وقد تم تعديل بعض العبارات، وحذف

العبارات التي تقل نسبة الاتفاق عليها عن 01\%٪، وقد تم حساب نسبة الاتفاق وفقًا لمعادلة (جتمان)

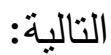

$$
\begin{aligned}
& \text { عدد مر ات الاتفاق } \\
& 1 \cdots x \\
& \text { عدد مر ات الاتفاق + عدد مرات الاختلاف } \\
& \text { نسبة الاتفاق = }
\end{aligned}
$$

r. صدق الاتساق الاخلي: وقد قام الباحث بحساب الاتساق الداخلي على عينة حجمها (·r) مفردة،

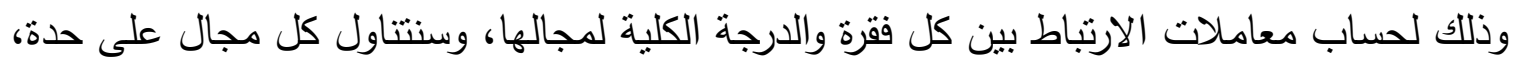

\begin{tabular}{|c|c|c|c|c|c|}
\hline الارتباط & رقم العبارة & الارتباط & رقم العبارة & الارتباط & رقم العبارة \\
\hline 947. & r) & $. .7 \times 1$ & 11 & $. t \tau \leqslant r$ & 1 \\
\hline$\because \vee \wedge \wedge$ & rt &.$V Y T$ & Ir & הז7. & r \\
\hline $.7 \vee 9$ & Tr & $. . V \times 1$ & $1 \pi$ & $. V Y \leq$ & r \\
\hline$\therefore V r$. & $r \varepsilon$ &.$\wedge \cdot V$ & $1 \varepsilon$ &.$V V V$ & $\varepsilon$ \\
\hline.$T \vee \wedge$ & ro & $.7 \leqslant 9$ & 10 &.$\vee \vee \neg \Lambda$ & 0 \\
\hline$\because \vee \leqslant \wedge$ & rT & $. .7 \leqslant V$ & 10 & $\because \vee \wedge \vee$ & 7 \\
\hline$\cdot .7 \cdot 1$ & TV & $\because \vee \vee \vee T$ & IV & .711 & v \\
\hline . .VM & rA & $.7 r 9$ & 11 & $\therefore V V$. & $\wedge$ \\
\hline דצד. & rq &.$v 01$ & 19 &. .779 & 9 \\
\hline $.7 \leqslant V$ & $r$. & . & $r$. & $.7 \leqslant 7$ & 1. \\
\hline
\end{tabular}
كما هو موضح في الجداول التالية:

$$
\text { جلول رقم (؛ ) يوضح }
$$

معاملات الارتباط بين درجة العبارات ودرجة البعد الذي تنتمي إليه

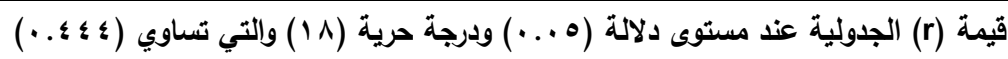

يتبين من الجدول السابق والخاص بمعاملات الارتباط بين كل عبارة من عبارات الانضباط

\begin{tabular}{|c|c|c|c|}
\hline مستوي الدلالة & معامل الارتباط مع الدرجة & أبعاد المقياس & p \\
\hline
\end{tabular}

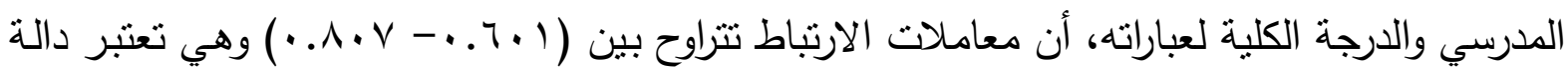

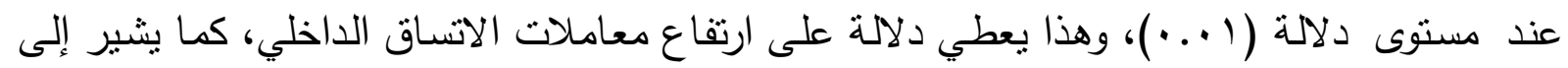
مؤشرات صدق مرتفعة وكافية يمكن الوثُوق بها في تطبيق الدراسة الحالية.

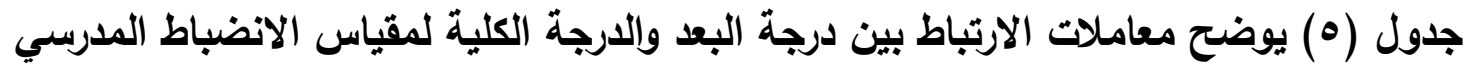




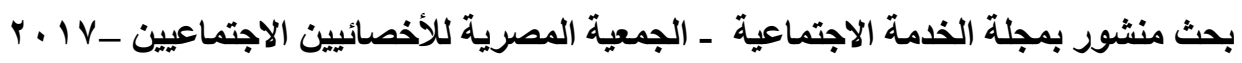

\begin{tabular}{|c|c|c|c|}
\hline$\cdot .1$ & .719 & التعامل مع الزملاء & 1 \\
\hline$\cdots 1$ & $\cdot v \cdot V$ & التعامل مع المعلمين & r \\
\hline$\cdot \cdot 1$ & $.71 T$ & الالتزام بالقواعد والقوانين المدرسي & r \\
\hline
\end{tabular}

قيمة (r) الجدولية عند مستوى دلالة (ه ...) ودرجة حرية (^l) والتي تساوي (؛ ؛ ؛ ..)

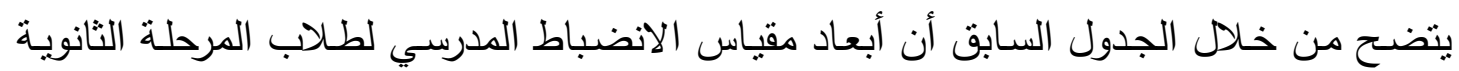

لها دلالة إحصائية عند مستوى ( ( . ·)، وهذا يعطي دلالة على ارتفاع معاملات الاتساق الداخلي، كما يشير إلى مؤشرات صدق مرتفعة وكافية يمكن الوثوق بها في تطبيق الدراسة الحالية. ب-الثبات: قام الباحث باستخدام طريقتين للنأكد من ثبات المقياس وهي:

ا. إعادة تطبيق المقياس: قام الباحث بحساب معامل ثبات المقياس، باستخدام طريقة (إعادة الاختبار Test-Retest تطبيقها على نفس العينة بعد فاصل زمني (0 1) يومًا أي بواقع أسبوعين بين التطبيق الأول والتاني، ثم قام الباحث بحساب معاملات الارتباط بين درجات الحالات في التطبيقين الأول والثاني باستخدام لئي لئي معامـل ارتبـاط بيرسـون، فكـان مقداره (VVA . • ) وهـو معامـل مرتفع القيمـة دال عند مسـتوى دلالـة (1 ( . ) مما يدل على أن مقياس الانضباط المدرسي لطلاب المرحلة الثانوية على درجة عالية من

r. طريقة ألفا كرونباخ: قام الباحث بقياس ثبات مقياس الانضباط المدرسي لطلاب المرحلة الثانوية، باستخدام معامل ثبات ألفا كرونباخ، والجدول التالي يوضح معامل الثبات أبعاد المقياس وهي:

$$
\text { جدول (7) يوضح }
$$

معامل ثبات ألفا كرونباخ لأبعاد مقياس الانضباط المدرسي لاى طلاب المرحلة الثانوية

\begin{tabular}{|c|c|c|}
\hline 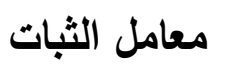 & 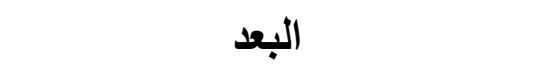 & الرقم - ام \\
\hline.$\vee V \vee 1$ & التعامل مع الزملاء & 1 \\
\hline $.7 \wedge 9$ & التعامل مع المعلمين & r \\
\hline..$T V V$ & الالتزام بالقواعد والقوانين المدرسية & $r$ \\
\hline.$v \cdot 1$ & الثبات الكي & \\
\hline
\end{tabular}

يوضتح الجدول السابق أن مقياس الانضباط المدرسي لطلاب المرحلة الثانوية يتمتع بثبات عالي

$$
\text { إحصائيًا دال عند مستوى دلالة ( ( . • ). }
$$

الأدوات الإحصائية المستخدمة:

SPSS- ) قام الباحث بتفريغ وتحليل البيانات من واقع المقياسين عبر برنامج التحليل الإحصسئي

20)، وتم استخدام الاختبارات الإحصائية التالية:

$$
\text { 1 - النسب المئوية والتكرارات. }
$$




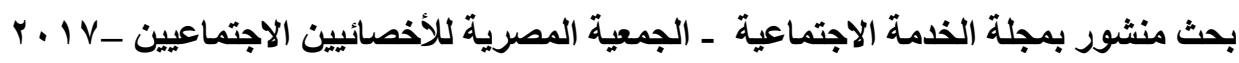

r- المتوسط الحسابي والانحراف المعياري.

r- اختبار (ألفا كرونباخ- Cronbach’s Alpha).

ع - معامل ارتباط (بيرسون - Pearson Correlation Coefficient ).

0- اختبار (ت- Independent Samples T-Test).

نتائجج الدراسةة:

أولاً: الوصف الإحصائي لعينة الدراسة وفق البيانات الشخصية:

وفيما يلي عرض لخصائص عينة الدراسة وفق البياتات الشخصية:

ويعتبر متغير العمر له أهمية كبيرة في وصف وتحديد خصائص عينة الدراسة من الطلاب،

حيث يوضح مدى النضج والوعي، علاوة على ذلك يوضح سمات المرحلة العمرية التي يقع فيها الطلاب عينة الدراسة، وهذا ما سوف يوضحه الجدول التالي:

جدول رقم (V) يوضح

توزيع أفراد العينة طبقًا لمتغير العمر

\begin{tabular}{|c|c|c|}
\hline النسبة المئوية & عدد & العمر \\
\hline$\Lambda . Y$ & 11 & 10 سنة \\
\hline$\{1.7$ & 91 & 7 ا سنة \\
\hline$\varepsilon 7.1$ & 1.1 & V سنة \\
\hline$\varepsilon .1$ & 9 & 1 ا سنة \\
\hline $1 \ldots$ & Y19 & الإجمالي \\
\hline \multicolumn{2}{|c|}{ צـ. 1 ا سنة } & المتوسط العمري \\
\hline
\end{tabular}

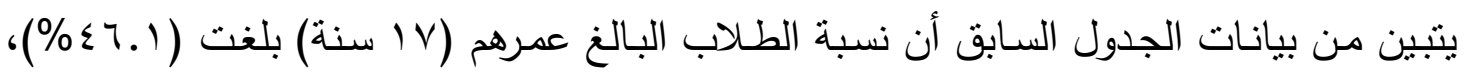

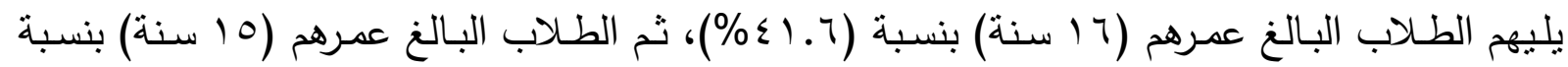

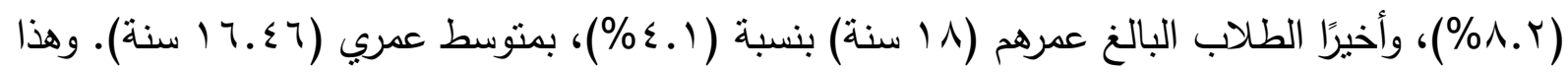
قـد يوضـح أن غالبيـة أفـراد عينـة الدراسـة مـن الطـلاب يقعـون في مرحلـة المراهقـة والتـي لهـا ســاتها وخصائصها المختلفة، من حيث التكوين الجسماني والعقلي والنفسي والانفعالي. والجنس أو النوع يعتبر متغير لله ثقله في وصف وتحديد خصائص عينة الدراسة من الطلاب، هذا بالإضافة إلى ارتباطه بنوعية السلوكيات التي يمارسوها والمشكلات التي قد يحدثوها، وهذا ما سوف يوضحه الجدول التالي:

\section{جدول رقم (^) يوضح}

توزيع أفراد العينة طبقًا لمتغير الجنس 


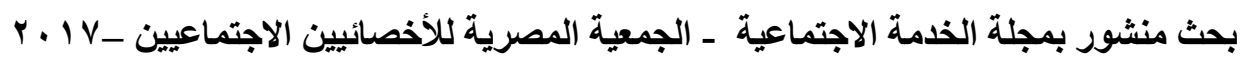

\begin{tabular}{|c|c|c|}
\hline النسبة المئوية & عدد & الجنس \\
\hline צ.T & $11 \mathrm{~V}$ & ذكر \\
\hline$\leq 7.7$ & $1 \cdot r$ & أنثي \\
\hline $1 \ldots$ & r) & الإجمالي \\
\hline
\end{tabular}

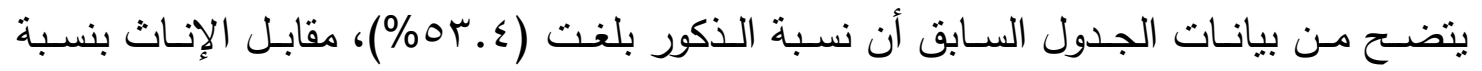

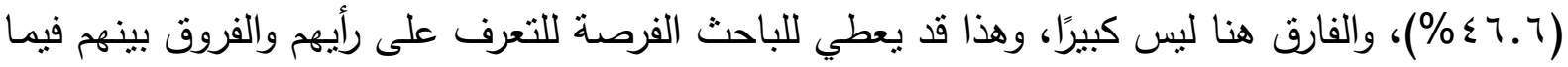

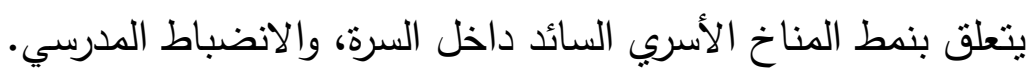
كما يعتبر متغير عدد الأخوات من أهم عوامل تحديد خصائص عينة الدراسة، وذلك من حيث

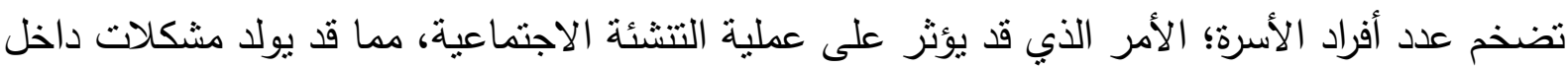

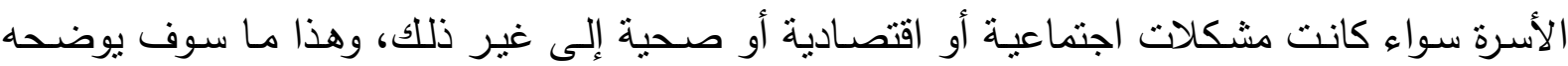

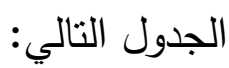

جدول رقم (9) يوضح

توزيع أفراد العينة طبقًا لمتغير عدد الأخوات

\begin{tabular}{|c|c|c|}
\hline النسبة المئوية & عدد & عدد الاخوات \\
\hline r.r & 0 & واحد \\
\hline Ir.r & $r V$ & اثنين \\
\hline 71.7 & o & ثلاثة \\
\hline rl & $\leq 7$ & أريعة \\
\hline r.V & 7 & خمسة \\
\hline $1 \ldots$ & r19 & الإجمالي \\
\hline \multicolumn{2}{|c|}{ } & متوسط عدد الإخوات \\
\hline
\end{tabular}

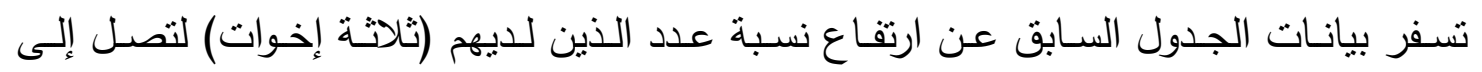

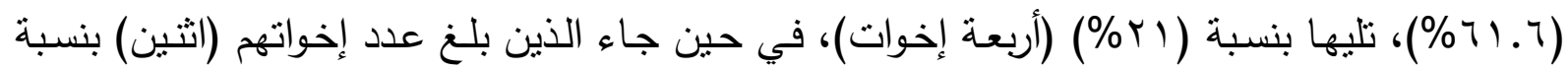

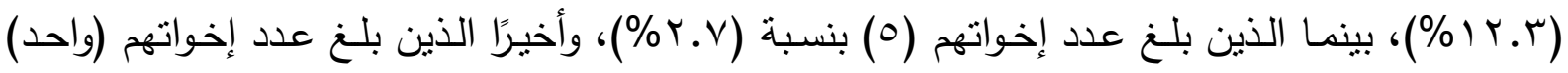

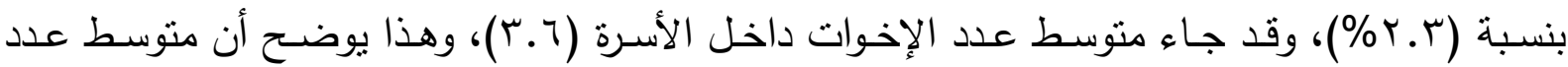

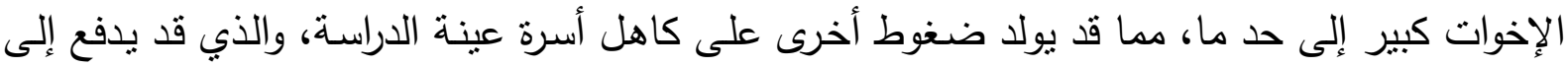

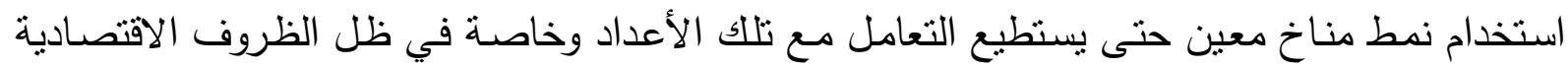
الحالية والتي يعاني منها الثعب المصري جميعًا.

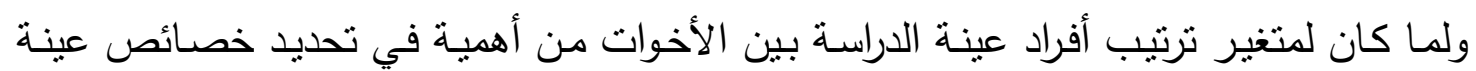
الدراسة، وذلك من حيث وضعه داخل الأسرة، وهذا ما سوف يوضحه الجدول النالي: 


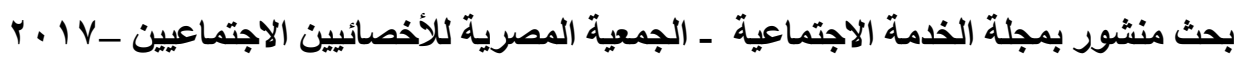

جدول رقم (· (1) يوضح

توزيع أفراد العينة طبقًا لمتغير ترتيبه بين الأخوات

\begin{tabular}{|c|c|c|}
\hline النسبة المئوية & عدد & الترتيب بين الأخوات \\
\hline$\Gamma \varepsilon . V$ & $V_{7}$ & الأول \\
\hline M. & 91 & الثاني \\
\hline Ir.V & $r$. & الثالث \\
\hline $1 \Lambda . V$ & $\leqslant 1$ & 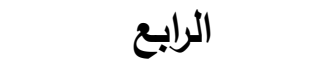 \\
\hline 1.1 & $\varepsilon$ & الخامس \\
\hline $1 \ldots$ & 1) & الإجمالي \\
\hline
\end{tabular}

تكثف بيانات الجدول السابق عن ارتفاع نسبة عدد الذين يكون ترتيبهم بين الأخوة في الترتيب

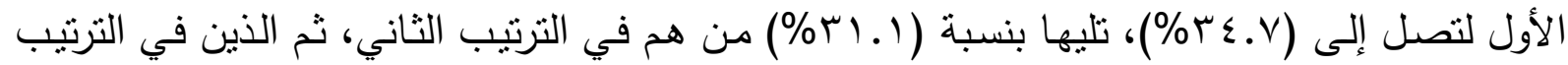

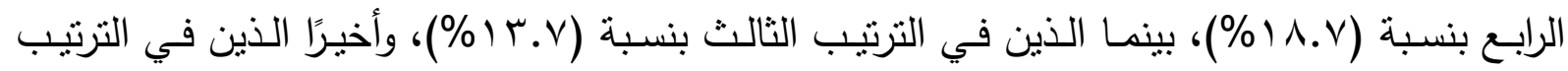

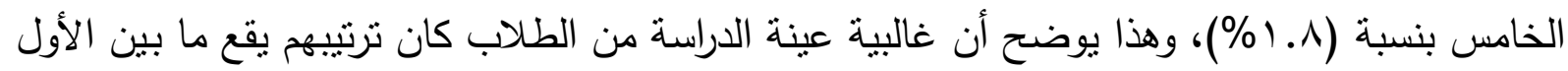

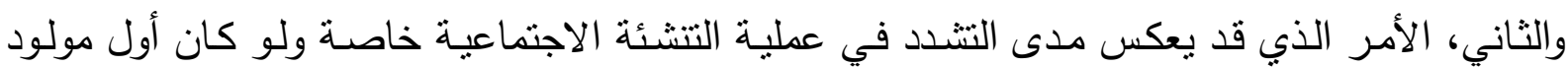
بنت، ومدى فرض الحماية الزائدة، على العكس لو كان الولا هو الذي يكون في الترتيب الأول فتكون هنا

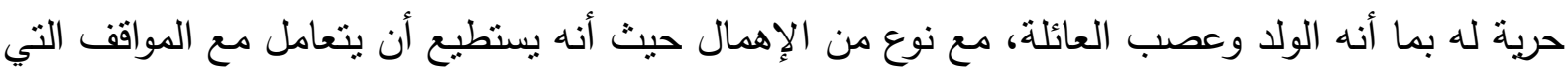

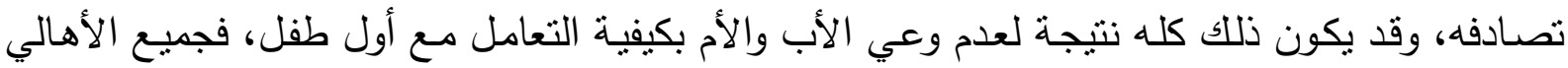

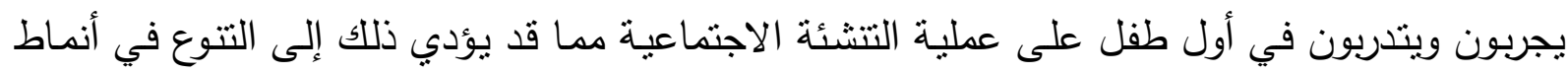

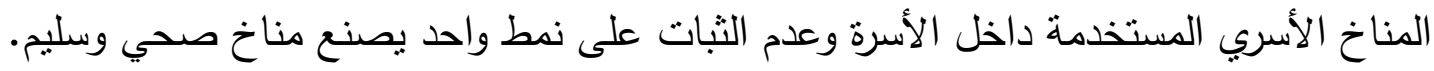

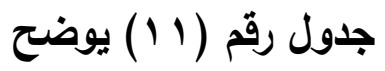

المتوسطات والانحرافات المعيارية لأنماط المناخ الأسري لاى عينة الدراسة

\begin{tabular}{|c|c|c|}
\hline الانحراف المعياري & المتوسط الحسابي & أنماط المناخ الأسري \\
\hline A.rVT & rr & الايمقراطي \\
\hline$\wedge .0 \ldots$ & M..人 & التسلطي \\
\hline$\vee . \wedge \leqslant \varepsilon$ & rV.A. & النبذ والإهمال \\
\hline 7. YVV & rq.Yr & الحماية الزائدة \\
\hline
\end{tabular}

تبرز نتائج الجدول ترتيب أنماط المناخ الأسري السائد داخل أسر عينة الدراسة؛ إذ يمثل نمط

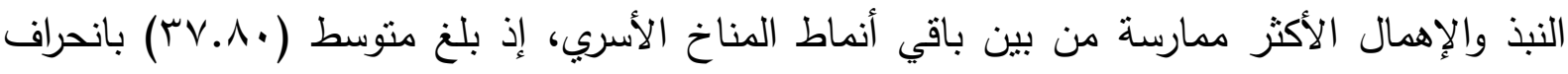

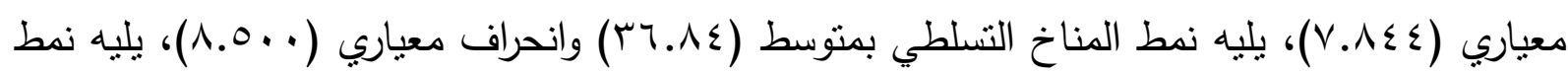




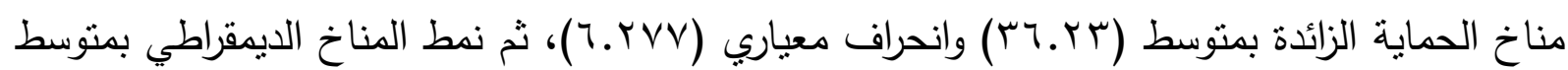

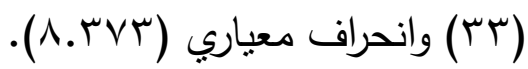
وهذا يثير إلى أن أكثر أنماط التفاعل داخل أسر عينة الدراسة يتتثل في نمط النبذ والإهمال والذي يعكس مدى الضغط المسيطر على طلاب المرحلة الثانوية عينة الدراسة، من تهميش وإهمال وعدم لفئه اهتمام كافي من قبل أفراد الأسرة وخاصة الآباء والأمهات، وبالتالي يؤثر ذلك على على نمو شخصية الكية الأبناء

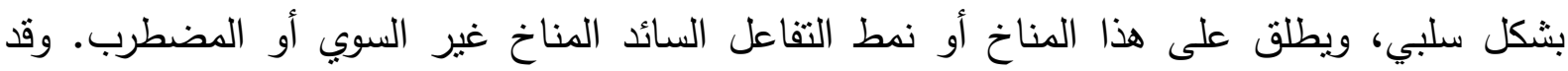

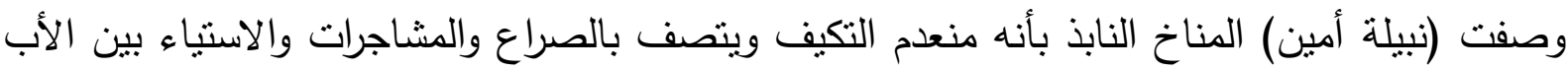
وأبنائه الذي يفتقر بدرجة كبيرة إلى العلاقات الاجتماعية السلبية، والنبذ يمكن أن يكون نبذًا دائمًا منذ

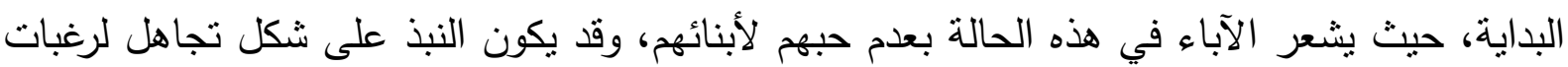
الأبناء وفي كلا النوعين فإن النتيجة واحدة وهي خروج طفل غير متكيف يميل إلى قضاء مزيد من وقته

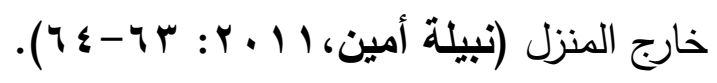

وتبين دراسة (Ledley, et.all.,2008) أن علاقات التعلق الآمن سببها والدان ينسمان

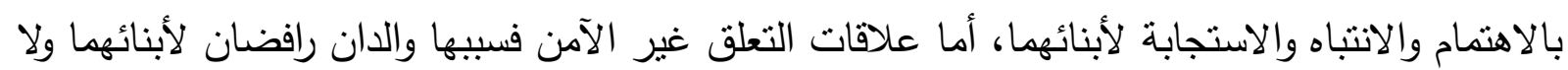
يمكن الاعتماد عليهم وقت الحاجة والضرورة. جدول رقم (Y I ) يوضح

المتوسطات والانحرافات المعيارية لأبعاد الانضباط المدرسي لاى عينة الدراسة

\begin{tabular}{|c|c|c|}
\hline الاتحراف المعياري & المتوسط الحسابي & أبعاد الانضباط المدرسي \\
\hline$\varepsilon . V \leq r$ & $r V . . T$ & التعامل مع الزملاء \\
\hline Y.7V & $1 \leq . \mu 1$ & التعامل مع المعلمين \\
\hline$\varepsilon . \leqslant$. & YV.r. & التعامل مع القوانين واللوائح المدرسية \\
\hline
\end{tabular}

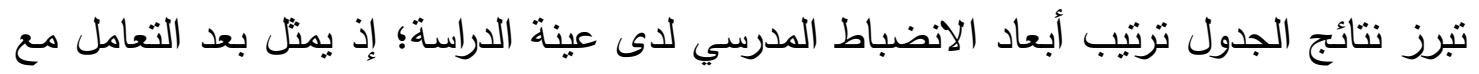

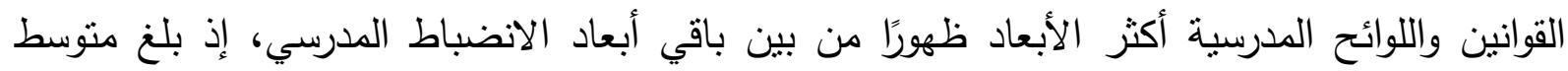

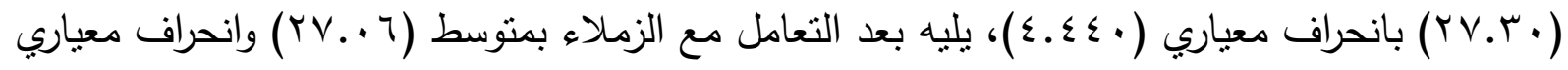

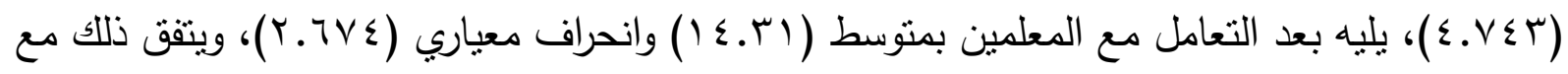
ما أثنارت إليه تقارير وأبحاث الحكومة الفيدرالية عن العنف وضعف انضباط الطلاب في مدارس استراليا

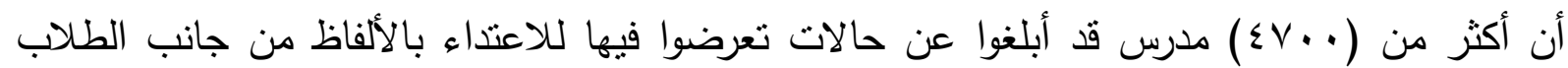

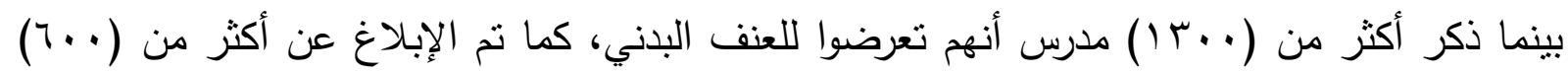

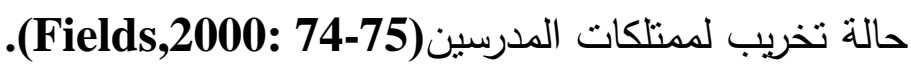


وتشير هذه النتائج إلى أن أكثر أبعاد الانضباط المدرسي تأثرًا لاى عينة الدراسة يتمنل في بعد التعامل مع القوانين واللوائح الدرسية والخروج عليها، والذي يعكس مدى الانحراف عن القواعد العامة

والسلوكيات المقبولة لدى عينة الدراسة، وبالتالي الخروج على القوانين المنظمة للعملية التعليمية.

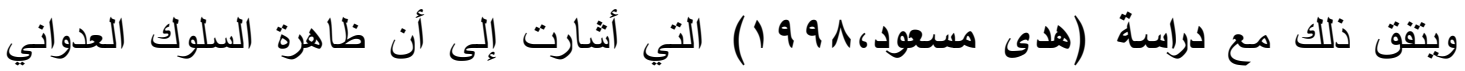
والخروج عن النظام المدرسي أصبحت منتشرة بين طلبة المرحلتين المتوسطة والثانوية والمتمنلة في: مشكلات التفاعل الصفي، ومشكلات مخالفة اللوائح والقوانين، ومشكلات التوافق الانفعالي، ولا تقتصر تلك المشكلات على الطلاب منخفضي التحصيل بل تمتد إلى الطلبة المتفوقين عقليًا وذلك في ظل غياب التي التوجيه السليم والرعاية المناسبة. وقد أظهرت دراسة (محمد السيد، ... . . أن لعدم الانضباط والعنف لدى الطلبة مظاهر

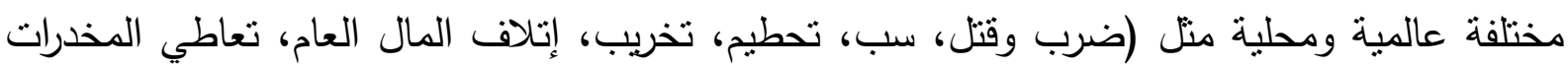
والكحوليات، الخروج عن النظام المدرسي، تحدى القوانين وغيرها)، كما يستخدم الطلاب في سلوكياتهم العنيفة الأسلحة الحادة، البيضاء، السلاسل، الجنازير وغيرها. وتوصلت دراسة (Curtis Albert,2000) إلى أن أنواع العنف والسلوك غير اللائق في المدارس يتمثل في: وجود كتابات خارجة على الجدران، نوافر المخدرات وزيادة في عدد الأسلحة

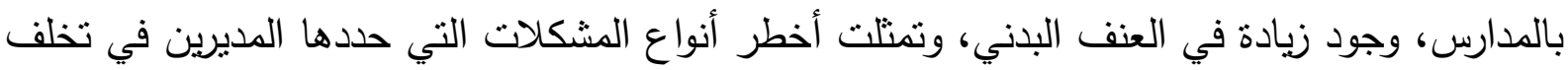
الطلاب وتغيبهم عن الدراسة.

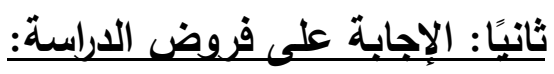
وفيما يلي عرض نتائج فروض الدراسة على النحو الثالي:

\section{فيما بتعلق بنتائج الفرض الأول:}

والذي ينص على: وجود فروق دالة إحصائًاً بين الذكور والإناث فيما يتعلق بأنماط المناخ

الأسري لدى طلاب المرحلة الثانوية. وللإجابة على هذا الفرض استخدم الباحث معامل اختبار (ت- T-test)؛ وذلك للكثف عن تلاك

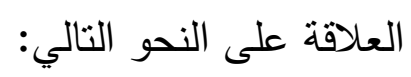

جدول رقم (r I ) يوضح

الفروق بين متوسطات درجات الذكور والإناث على مقياس أنماط المناخ الأسري لاى طلاب المرحلة الثانوية

\begin{tabular}{|c|c|c|c|c|c|c|}
\hline مستوى الدلالة & قيمة T & درجة الحرية & المعراري & المتوسط & النوع & الأسطري المناخ \\
\hline \multirow{2}{*}{ (الة عذ } & \multirow{2}{*}{ r.rrv } & \multirow{2}{*}{ riv } & 9.795 & ro..r & ذكر & \multirow{2}{*}{ الديمقراطي } \\
\hline & & & $7.0 \mathrm{~V} \varepsilon$ & צ.T.Y & أنثي & \\
\hline \multirow{2}{*}{ دالة عند } & \multirow{2}{*}{ r.AIr } & \multirow{2}{*}{ riv } & $v .911$ & ro.1s & ذكر & \multirow{2}{*}{ التسلطي } \\
\hline & & & $\Lambda . V \leqslant r$ & rA.rr & أنثي & \\
\hline
\end{tabular}




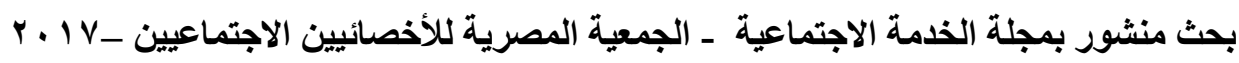

\begin{tabular}{|c|c|c|c|c|c|c|}
\hline \multirow{2}{*}{ دالة عند } & \multirow{2}{*}{ Ir.s.ro } & \multirow{2}{*}{ riv } & $7 . \wedge \leq$ & rr.s. & ذكر & \multirow{2}{*}{ الحماية الزائدة } \\
\hline & & & r.sor & \&.. & أنثي & \\
\hline \multirow{2}{*}{ دالة عند } & \multirow{2}{*}{$19.1 \mathrm{r}$} & \multirow{2}{*}{ riv } & $r . q \leq \varepsilon$ & $\leq \varepsilon . \leqslant \leq$ & ذكر & \multirow{2}{*}{ النبذ والإهمال } \\
\hline & & & $0 . \leqslant Y q$ & Mr.s. & أنثي & \\
\hline \multirow{2}{*}{ دالة عند } & \multirow{2}{*}{ r.ror } & \multirow{2}{*}{ YIV } & YV. & $1 \leq V . .1$ & ذكر & \multirow{2}{*}{ إجمالي المقياس } \\
\hline & & & r r. & $1 \leqslant r . r$. & أنثي & \\
\hline
\end{tabular}

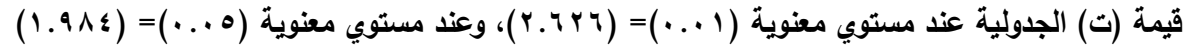

يتبين من الجدول السابق وجود فروق ذات دلالة إحصائية بين متوسطات درجات الذكور والإناث

على أنماط المناخ الأسري، وهذا يثير إلى ثبوت صحة الفرض الأول، وذلك على النحو التالي: بالنسبة لنمط المناخ الأسري الديمقراطي، فقد جاء متوسط الذكور (r...0r) وانحراف معياري

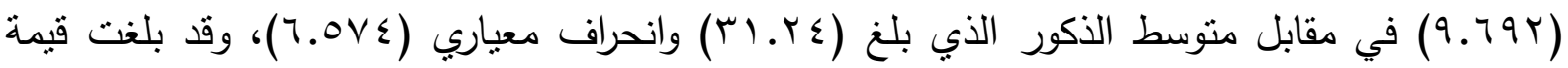
(ت) المحسوبة (Vr.r.r)، وهذا يعنى أن (ت) المحسوبة أكبر من (ت) الجدولية، مما بدل على وجود فروق دالة إحصائًًا عند مستوى معنوية (1 . . ) بين منوسطات درجات الذكور والإناث، لصالح الطلاب الذكور؛ وقد يرجع ذلك إلى أن الأسرة العربية بشكل عام والأسرة المصرية بشكل تعطي حرية التعبير والرأي للذكور أكثر من الإناث والخروج والرجوع بحرية دون التقيد بمواعيد معينة مقارنة بالإناث، وقد

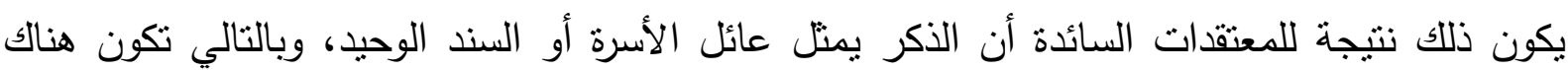
حرية أكبر للذكور على الإناث. وسيادة نمط المناخ الأسري الديمقراطي داخل الأسرة يزيد من زيادة التفاعل داخل الأسرة وتكوين الثخصية السوية، وقد يتفق ذلك مع ما أثنار إليه (أحمد عبد اللطيف، سامي محسن) حيث أشثارا إلى أن الثخصية السوية هي التي تتشأ في جو تشيع فيه التقة والوفاء والحب والتآلف والأسرة التي تحترم فردية الثخص، وتدربه على احترام نفسه، وتساعده على أن يحافظ على كرامته بين الناس، وتوحى إلبه بالثقة اللازمة لنموه، هي الأسرة المستقرة والهادئة، من ناحية العلاقات التي تتعكس ثقتها على أطفالها (أحمد

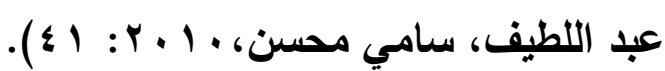
وقد توصلت دراسة (إيناس محمد، ب . . r) إلى أن المناخ الأسري السوي يساعد على إثباع الحاجات النفسية للمراهقين وخاصة الحاجة للحب والانتماء وتحقيق الذات، وأثارت دراسة (عمرو محمد، I . . إلى أنه كلما زاد الاستقلال للأبناء زادت قدرتهم على تحديد الهدف، وكلما زاد التفاعل الأسري وزادت حرية الأبناء في التعبير عن مشناعرهم زادت قدرة الأبناء على تحويل القرارات إلى أعمال وزادت قدرتهم على تتفيذ الأعمال المطلوبة.

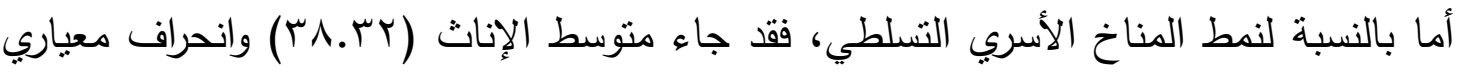
(^.V乏Y) (ت) المحسوبة (Y (Y.イ)، وهذا يعنى أن (ت) المحسوبة أكبر من (ت) الجدولية، مما يدل على وجود 
فروق دالة إحصائيًا عند مستوى معنوية (1 ...) بين منوسطات درجات الذكور والإناث لصالح الإناث،

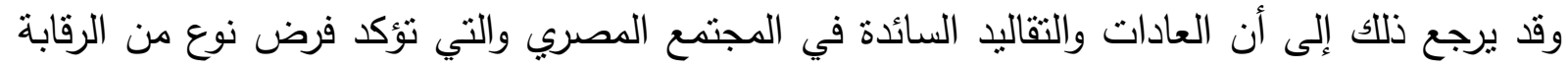
على الفتاة وعدم إعطائها حرية التعبير، علاوة على فرض الطاعة الواجبة عليها دون نقاش.

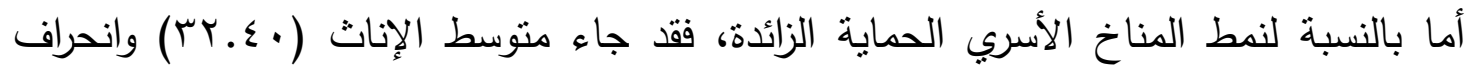

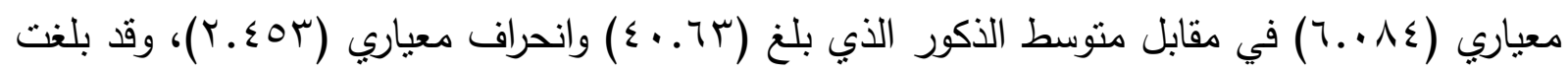

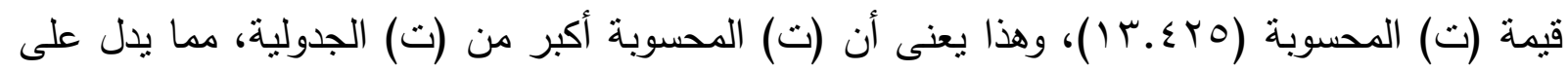

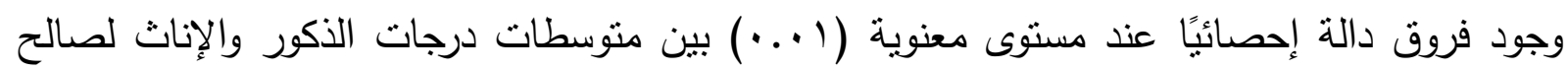

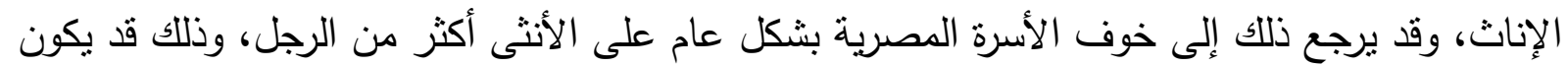

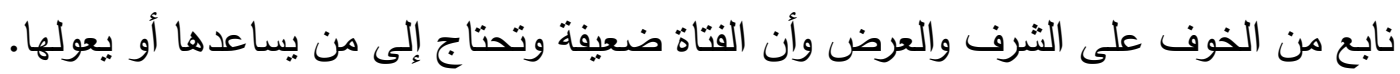

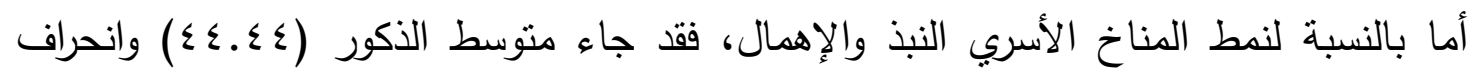

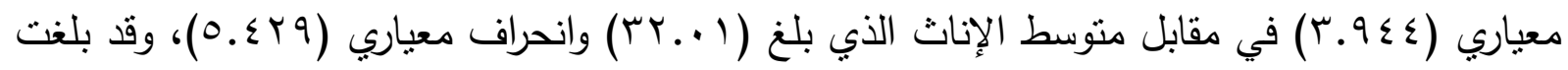

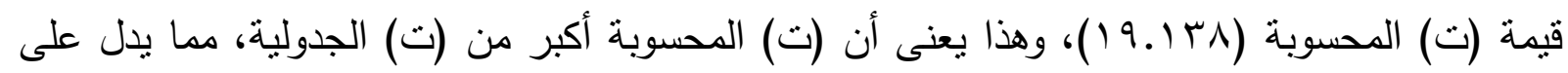

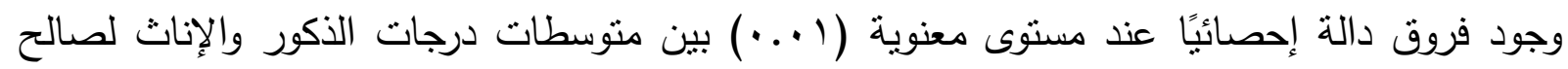

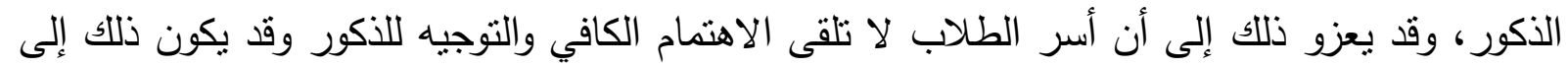

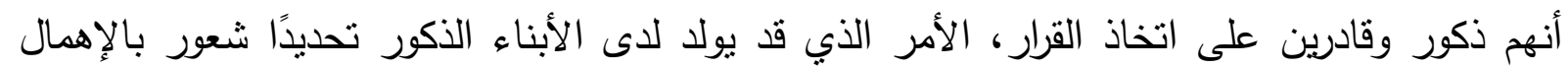

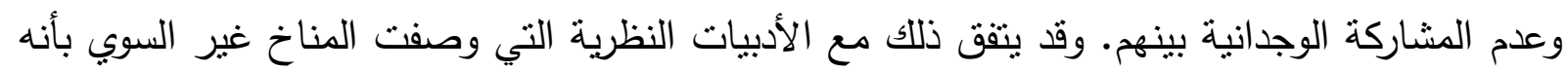

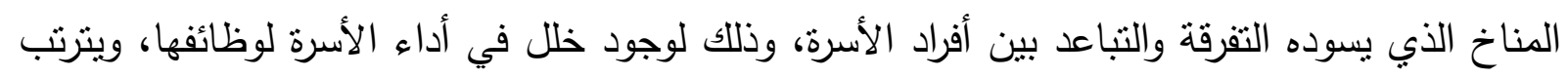

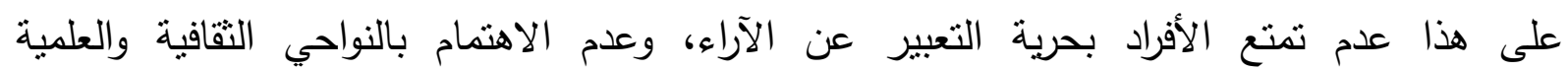

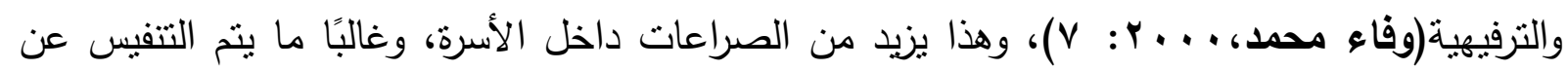

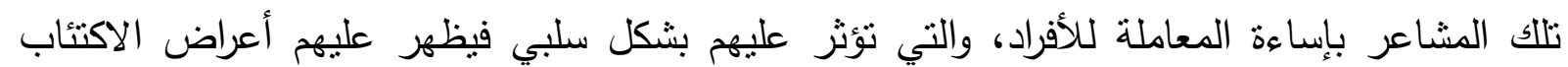

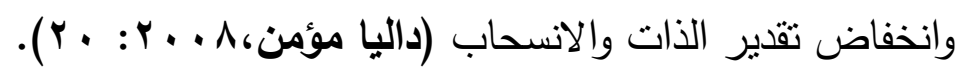

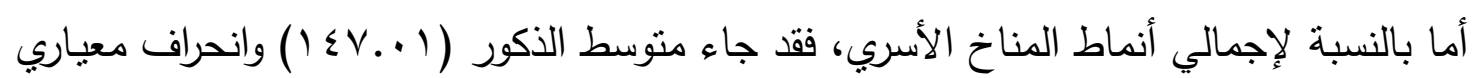

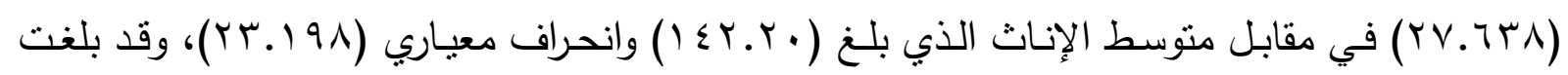

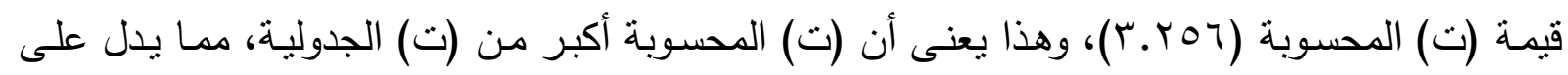

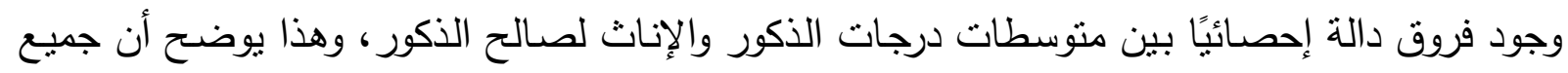

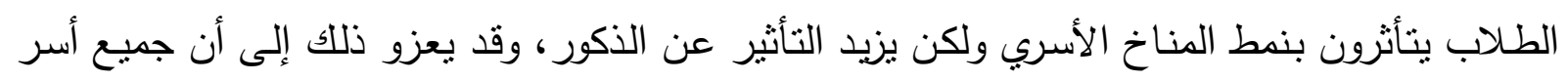

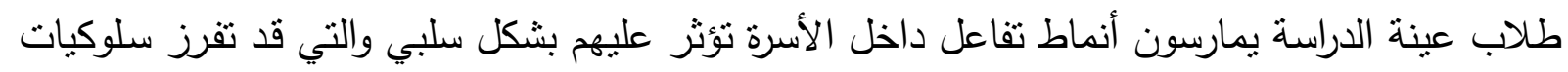
غير مقبولة اجتماعيًا مما قد يولد حالة من عدم الانضباط. فيما يتعلق بنتائج الفرض الثاني: 
والذي ينص على: وجود فروق دالـة إحصـائًاً بين الذكور والإناث فيما يتعلق بأنماط المناخ

الأسري لاى طلاب المرحلة الثانوية. وللإجابة على هذا الفرض استخدم الباحث معامل اختبار (ت- T-test)؛ وذلك للكثف عن تلك

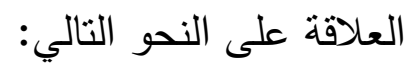

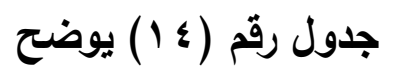

الفروق بين متوسطات درجات الذكور والإناث على مقياس الانضباط المدرسي لدى طلاب المرحلة الثانوية

\begin{tabular}{|c|c|c|c|c|c|c|}
\hline مستوى الدلالة & قيمة T & درجة الحرية & الانحراف & المتوسط & النوع & الانضباط \\
\hline \multirow{2}{*}{ دالة عند } & \multirow{2}{*}{17.797} & \multirow{2}{*}{ YIV } & 1.11. & $r . . \leqslant r$ & ذكر & \multirow{2}{*}{ التعامل مع } \\
\hline & & & $\varepsilon .079$ & $r \leq .1 \leq$ & أنثي & \\
\hline \multirow{2}{*}{ دالة عند } & \multirow{2}{*}{1.07.} & \multirow{2}{*}{ YIV } & r...rY & $10.9 \mathrm{~V}$ & ذكر & \multirow{2}{*}{ المعامل مع } \\
\hline & & & r.r.o & Ir.Ao & أنثي & \\
\hline \multirow{2}{*}{ دالة عند } & \multirow{2}{*}{$1 . .0 r$. } & \multirow{2}{*}{ YIV } & r.ru & $r \ldots q$ & ذكر & \multirow{2}{*}{ القوانين واللوائح } \\
\hline & & & $r .9 \leq \varepsilon$ & $r \leq . q$. & أنثي & \\
\hline \multirow{2}{*}{ دالة عند } & \multirow{2}{*}{$1 \mu . \Lambda \cdot \Lambda$} & \multirow{2}{*}{ YIV } & $0 . \wedge \wedge \vee$ & A..Y० & ذكر & \multirow{2}{*}{ إجمالي المقياس } \\
\hline & & & $9 . \wedge \leq Y$ & VI.rr & أنثي & \\
\hline
\end{tabular}

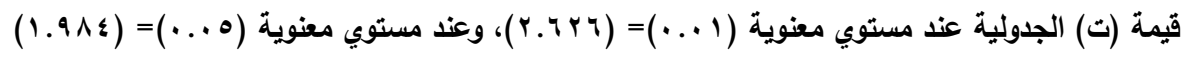

يتبين من الجدول السابق وجود فروق ذات دلالة إحصائية بين متوسطات درجات الذكور والإنات

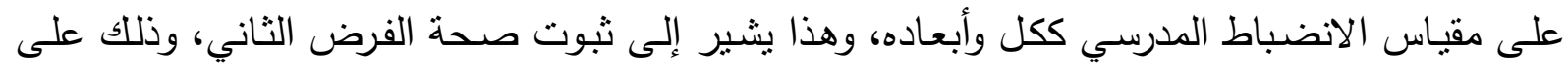

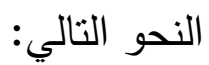

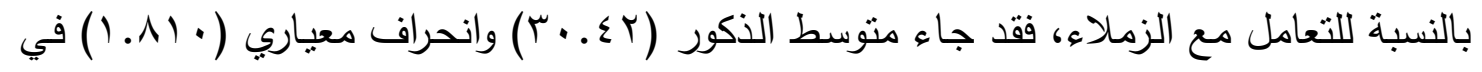

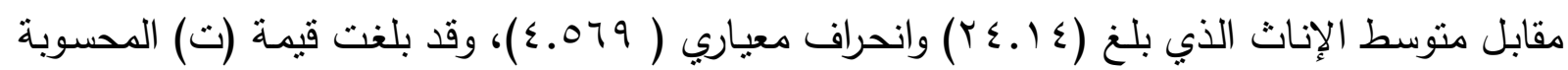

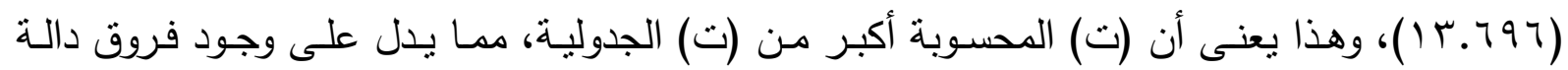

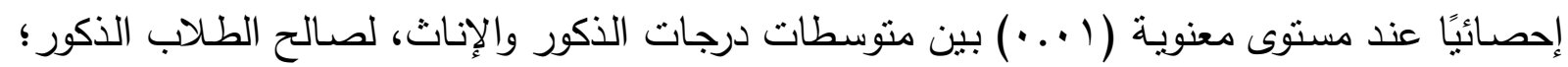

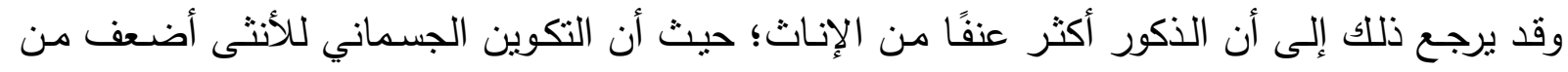

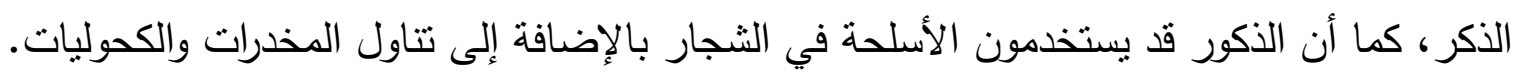

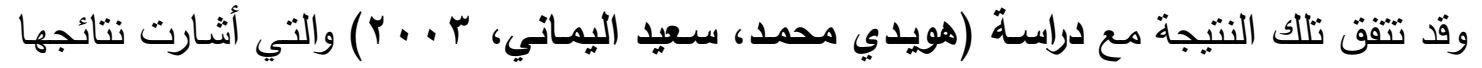
إلى أن السلوكيات غير المقبولة أكثر انتشارًا لدى الذكور من الإناث.

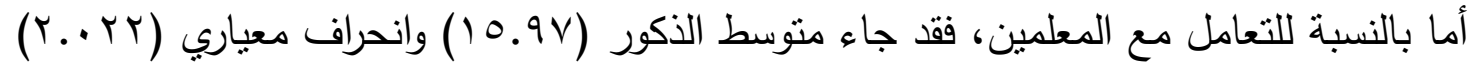

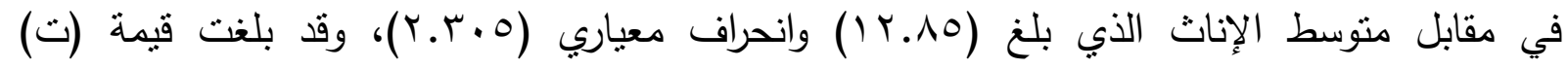

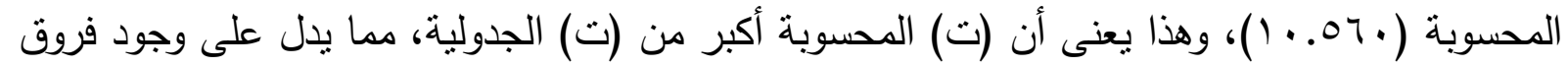


دالة إحصائًا عند مستوى معنوية (1 ...) بين متوسطات درجات الذكور والإناث لصالح الذكور، وقد يرجع ذلك إلى أن الذكور أجرأ من الإناث علاوة على أنها أكثر خوفًا وخلاً.

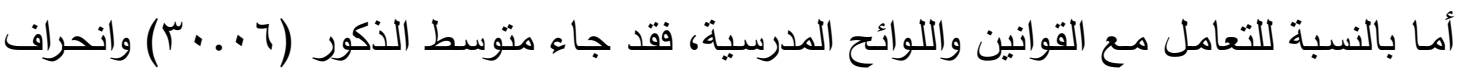

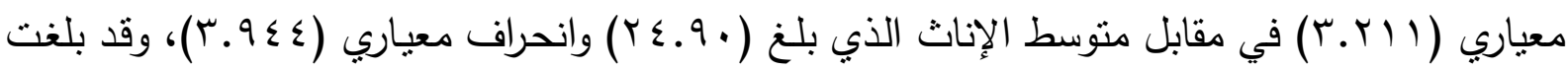
قيمة (ت) المحسوبة ( • or. • ()، وهذا يعنى أن (ت) المحسوبة أكبر من (ت) الجدولية، مما يدل على وجود فروق دالة إحصائًا عند مستوى معنويـة ( ( . •) بين متوسطات درجات الذكور والإناث لصـالح الذكور، وقد يرجع ذلك إلى أن الذكور الأكثر هربًا من المدرسـة للعب وعدم الانتظام في الدراسـة، على معلى عكس الفتاة التي تكون أكثر حرصًا على الالنزام والحضور والاهتمام بالواجبات، بالإضافة إلى أن القواعد الأسـرية والسيطرة التي تفرض على الفتاة في الأسـرة تؤثر عليها وعلى التزامها إلى حد مـا بالقواعد

وتتفق تلك النتيجة مع دراسة (نظمي أبو مصطفى، عطاف أبو غالي، ؛ . . ب) والتي أكدت على

وجود فروق جوهرية بين الذكور والإناث في مجال العنف ضد الممنلكات العامة المدرسية لصالح الذكور .

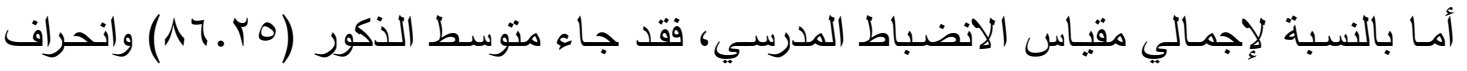

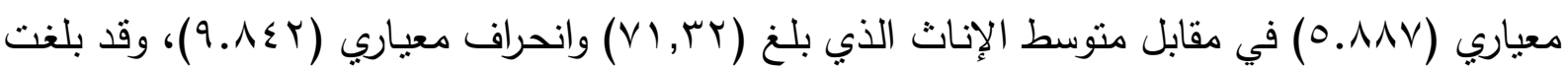

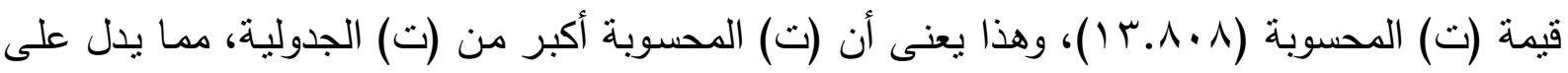
وجود فروق دالة إحصـائًا عند مستوى معنوية ( ( . •.) بين متوسطات درجات الذكور والإناث لصالح الذكور ، وقد يرجع ذلك إلى أن الذكور أكثر مشـاغبة من الإنـاث وهذا يتفق مسع دراسـة (سميحة أبـو

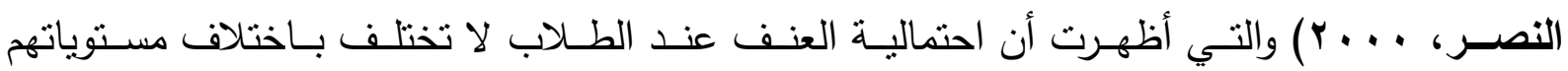
الاجتماعية والاقتصادية، كما بينت الدراسة ظاهرة العنف لصالح الذكور . فيما بتعلق بنتائج الفرض الثالث: والذي ينص على: وجود علاقة دالة إحصائيًا بين أنماط المناخ الأسري والانضباط المدرسي لدى طلاب المرحلة الثانوية. وللإجابـة على هذا الفرض استخدم الباحث معامل ارتباط (بيرسون -Pearson Correlation)؛ وذللك للكثف عن تللك العلاقة على النحو التالي: جدول رقم (10) يوضح

العلاقة بين أنماط المناخ الأسري والانضباط المدرسي لاى طلاب المرحلة الثانوية

\begin{tabular}{|c|c|c|c|c|}
\hline الارجة الكلية لمقياس & التعامل مع القوانين & التعامل مع & التعامل مـع & المتغير \\
\hline * . & $" .01 r$ & $* *$. ros & $* *, \cdot r \cdot r$ & الديمقراطي \\
\hline$" *$ ". rrI & $"-.1 \leq$ & $" * \| 1 \wedge r$ & "-. r r rV & التسلطي \\
\hline$" *-. \wedge \vee \wedge$ & $" *-\cdot v \cdot \Lambda$ & "*.- .717 & $"=. .994$ & الحماية الزائدة \\
\hline
\end{tabular}




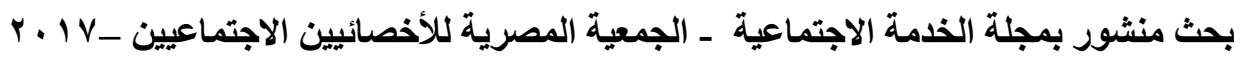

\begin{tabular}{|c|c|c|c|c|}
\hline$"-. . \wedge 0$. & $" * . . \vee V r$ & $" *-. \wedge \cdot v$ & $" *-. V \cdot r$ & النبذ والإهمال \\
\hline$" . \wedge 00$ & $" * \vee \wedge \vee$ & $" . .4 \Lambda$. & ". .v4r & إجمالى مقياس أنماط المناخ الأسري \\
\hline
\end{tabular}

يتضح من الجدول السابق وجود علاقة ارتباطية طردية دالة إحصائيًا عند مستوى (1 ... ) بين إجمالي مقياس أنماط المناخ الأسري وأبعاد مقياس الانضباط المدرسي لدى طلاب المرحلة الثانوية، مما يؤكد ثبوت صحة الفرض الثالث. وهذا يعني أنه كلما انخفضت أنماط المناخ الأسري لاى عينة الدراسة من طلاب المرحلة الثانوية كلما انخفض الانضباط المدرسي للديهم، والعكس كلما زاد تحسن أنماط المناخ زاد الانضباط المدرسي لهم؛ وقد يرجع الباحث ذلك إلى المناخ الأسري ونمط التفاعل السائد يؤثز سواء بشكل إيجابي أو بشكل سلبي على سلوكيات الأبناء؛ الأمر الذي ينعكس على انضباطهم بالمدرسة سواء من خلال التعامل مع الزملاء أو المعلمين أو القوانين واللوائح المدرسية.

وبشكل عام يؤثز نمط التفاعل السائد في الأسرة على اختيارات الأبناء وقراراته، وهذا ما أوضحته دراسة (سهير إبراهيم، I . . Y) وجود علاقة بين أساليب الاتصال السائدة في الأسرة وبين اختيار جماعة الرفاق ذات السلوكيات المرغوبة وغير المرغوبة، حيث توجد علاقة بين أسلوب الاتصال الديمقراطي السائد في الأسرة وبين اختيار الأبناء لجماعة الرفاق ذات السلوكيات المرغوبة، بينما توجد علاقة بين أسلوب الاتصال التساهلى السائد في الأسرة وبين اختبار الأبناء لجماعة الرفاق ذات السلوكيات غير المرغوبة، وتوجد علاقة بين أسلوب الاتصال التسلطي السائد في الأسرة وبين اختيار الأبناء لجماعة الرفاق ذات السلوكيات المرغوبة وغير المرغوبة.

كما توصلت دراسة (أولجا أنطوان ، ه . . ب) للعديد من النتائج أهمها أن للأسرة تأثثر واضح على تفشي ظاهرة العنف بين طلاب مدارس التعليم الثانوي بنوعيها (الثانوي والفني). كما تبين مسن الجدول أيضًا وجـود علاقـة ارتباطيـة طرديـة دالـة إحصـائيًا عند مستوى معنويـة ( ( . · ) بين نمط المناخ الأسري الديمقراطي وإجمالي مقياس الانضباط المدرسي وأبعاده (التعامل مـع الزملاء، التعامل مـع المعلمين، التعامـل مـع القوانين واللوائح المدرسية)، وهذا يعنـي أنه كلمـا زاد نمط المناخ الأسري الديمقراطي كلما زاد الانضباط المدرسي وتحسن، والعكس كلما انخفض استخدام هذا النمط الديمقراطي كلما انخفض الانضباط المدرسي بأبعاده. ويسـفر الجدول أيضًا عـن وجـود علاقـة ارتباطيـة عكسية دالـة إحصـائًا عندـ مستوى معنويـة (1 ( . •) بين نمط المنـاخ الأسـري التسـلطي وإجمالي مقياس الانضباط المدرسي وأبعـاده (التعامـل مـع الزملاء، التعامل مـع المعلمين، التعامـل مـع القوانين واللوائح المدرسية)، وهذا يعنـي أنه كلمـا زاد نمط المناخ الأسري التسلطي كلما انخفض الانضباط المدرسي بأبعاده، والعكس كلما انخفض استخدام هذا

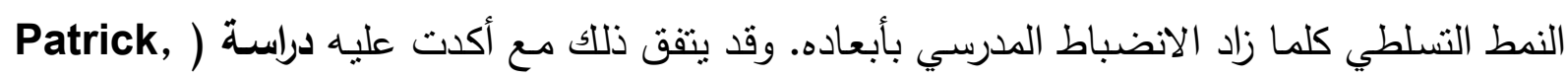
2005) على أن العلاقة بين الابن والوالدين التي تسودها التسلط والحدة في التواصل بينهما سـاعدت 
على زيادة الشكلات السلوكية لاى الأبناء عبر مراحل الدراسة المختلفة من مرحلة الطفولة الوسطى إلى المتأخرة.

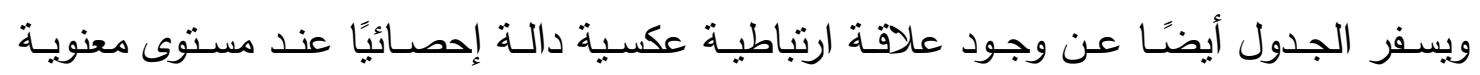

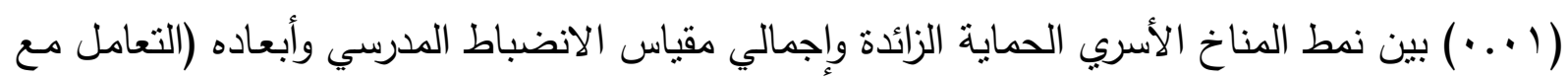

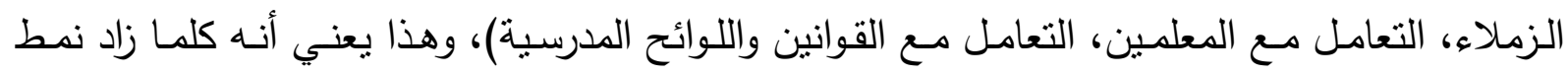

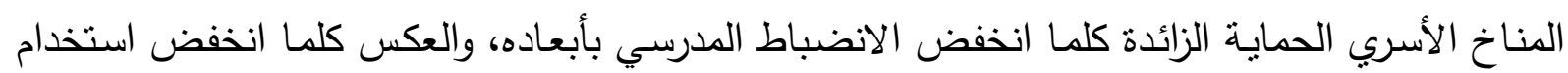
نمط الحماية الزائدة كلما زاد الانضباط المدرسي بأبعاده.

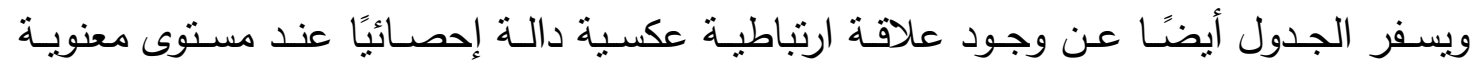

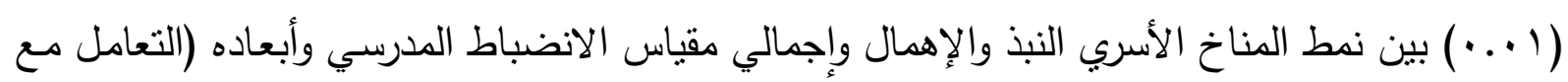

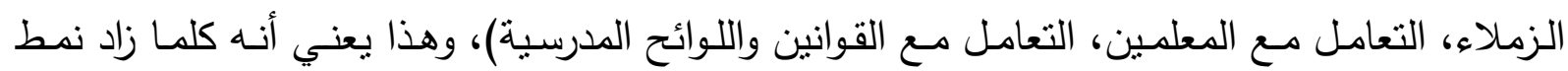

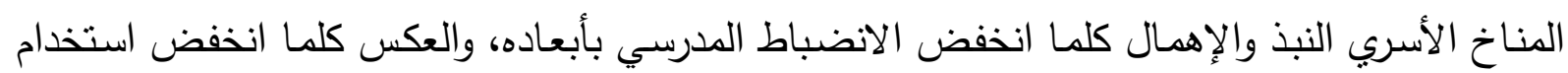

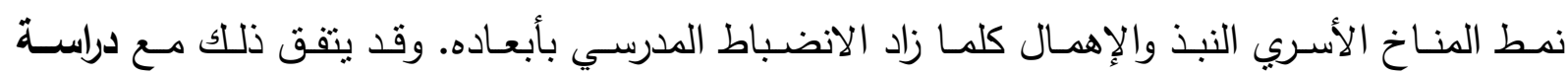
(مصطفي إسماعيل، 17 • r) والتي انتهت إلى وجود علاقة دالة إحصائيًا بين أساليب المعاملة الوالدية

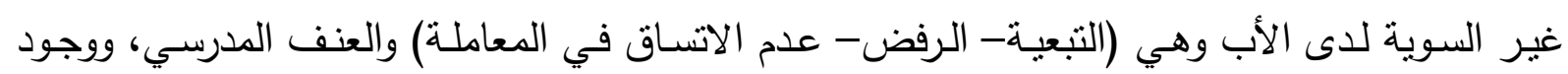
علاقة ارتباطية دالة إحصائيًا بين أساليب (الإهمال- الرفض- التتدد- عدم الاتساق في المعاملة). 
1. أحمد عبد اللطيف أبو أسعد، سامي محسن (11 + r): سيكولوجية المشكلات الأسرية، دار الميسرة للنشر والتوزيع، طا، عمان.

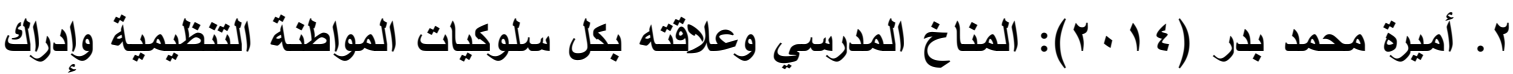

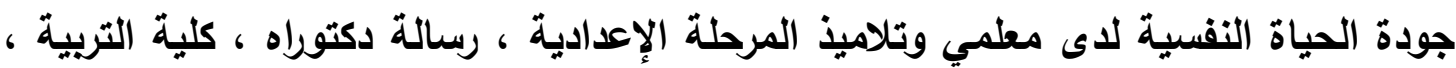
جامعة الزقازيق.

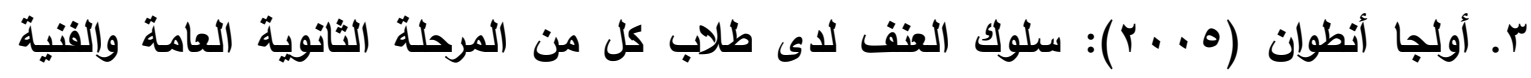

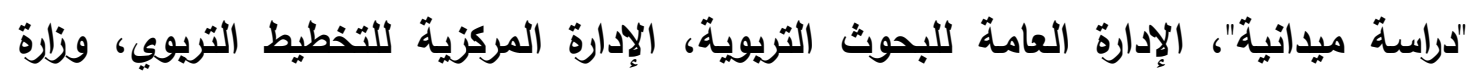
التعليم.

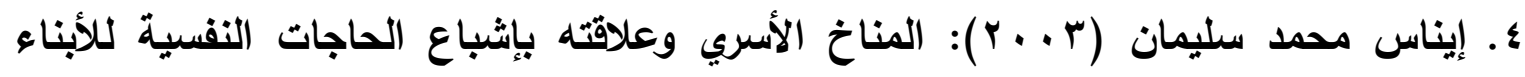
المراهقين، رسالة ماجستير، معهد الدراسات التربوية، القاهرة.

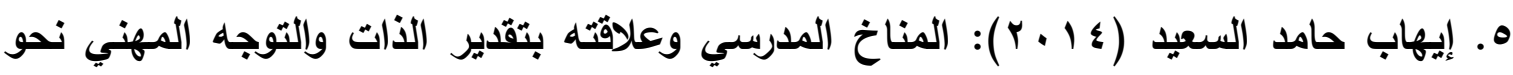

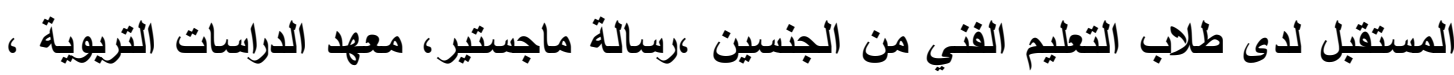
جامعة القاهرة

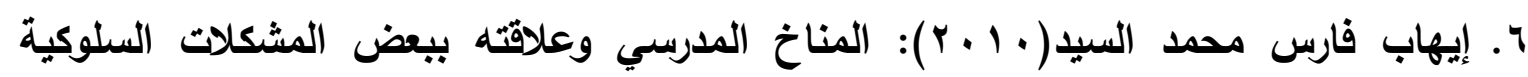

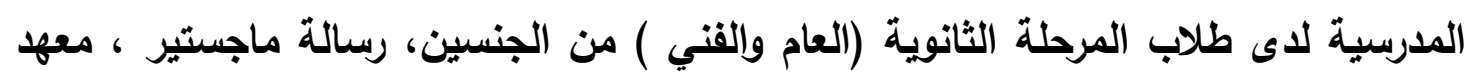
الاراسات التريوية، جامعة القاهرة. V. تقرير التنمية البشرية (10 (Y): برنامج الامم المتحدة الإنمائي ، التنمية في كل عمل ، نيويورك.

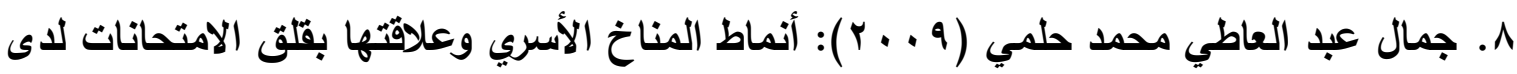

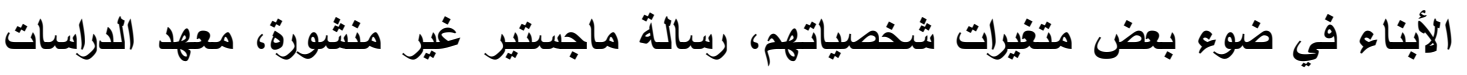
والبحوث التريوية، جامعة القاهرة.

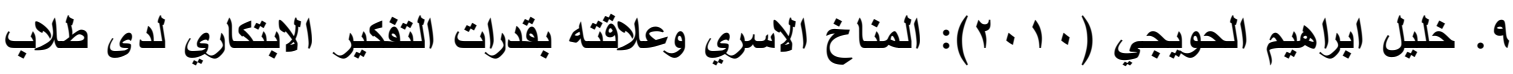

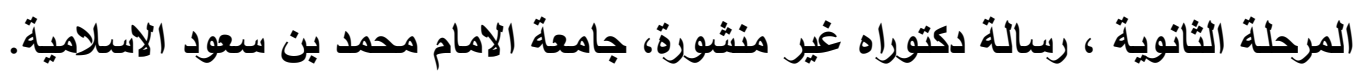

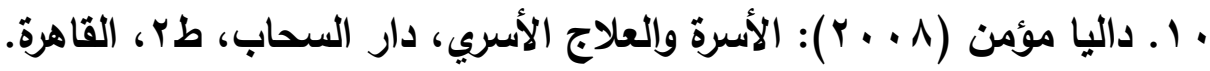

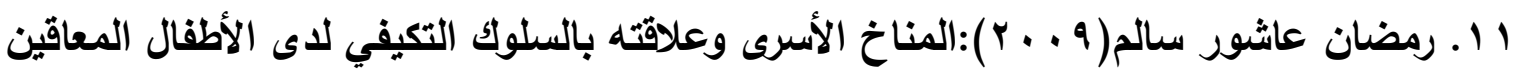

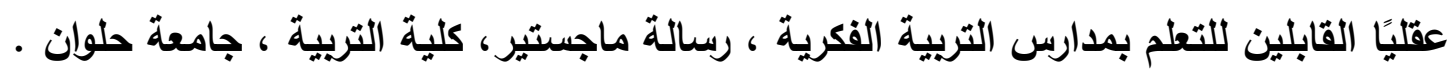

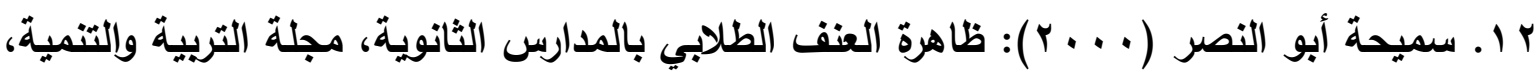
العدد (Y ا Y)، السنة الثامنة، القاهرة. 
ب ا ـ سهير إبراهيم محمد (1 . . r): العلاقة بين شبكة الاتصال داخل الأسرة ويبن اختيار المراهقين لجماعة الرفاق غير السوية، رسالة ماجستير، كلية البنات، جامعة عين شمس.

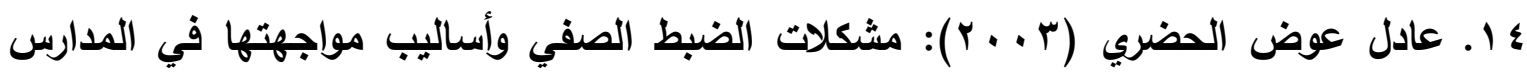
الثانوية بسلطنة عمان من وجهة نظر المعلمين والأخصائيين الاجتماعيين، رسالة ماجستير، جامعة السلطان قابوس.

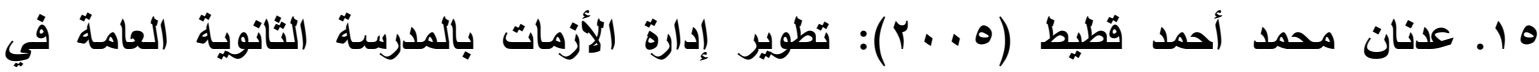
جمهورية مصر العربية في ضوء الفكر الإداري المعاصر، مجلة التربية والتعليم، العدد (ه广)، المركز القومي للبحوث التربوية والتنمية، القاهرة.

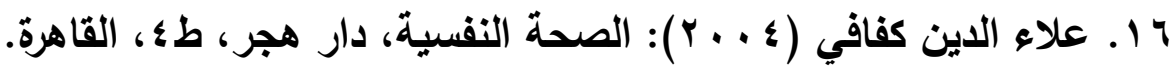

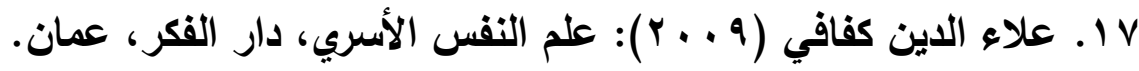
1 1. على عبد الله (1 . . ץ): جودة الحياة لاى عينة من الراشدين في ضوء بعض المتغيرات الايمغرافية، المجلة المصرية للاراسات التفسية، المجلد (ع)، أكتوير، القاهرة.

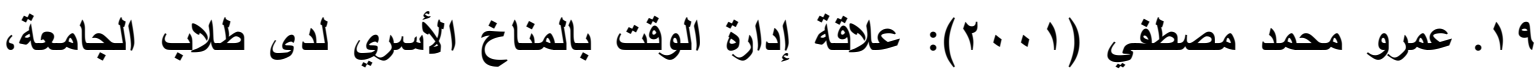
رسالة ماجستير، كلية الاقتصاد المنزلي، جامعة حلوان.

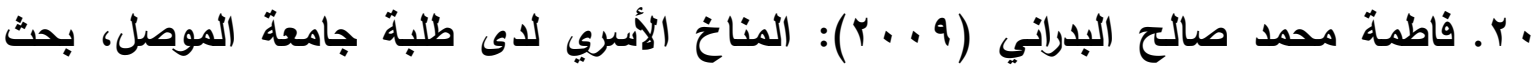
منشور في مجلة أبحاث كلية التربية الأساسية، المجلد (^) العدد (ع)، كلية العلوم الإسلامية، جامعة الموصل، العراق.

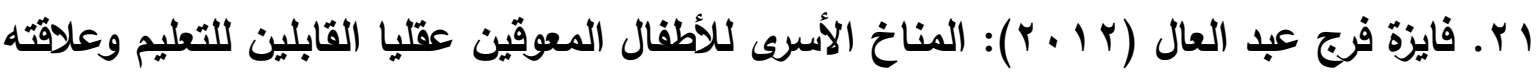
بالسلوك التكيفي لايهم ، رسالة ماجستير ، معهد الدراسات التربوية، جامعة القاهرة.

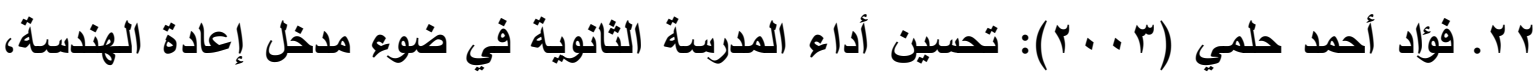
مجلة التربية، العدد (^)، الجمعية المصرية للتربية المقارنة والإدارة التعليمية، القاهرة. ب r. . مجدي ماهر مسيحة (999 19): المشكلات التي تواجه طلاب التعليم الثانوي الفني الصناعي والآثار النفسية المترتبة عليها، المركز القومي للبحوث التريوية والتنمية، القاهرة. ع ץ. محمد السيد حسونة ( . . . ץ): العنف لاى طلبة المدارس الثانوية في مصر، المركز القومي للبحوث التريوية والتتمية، القاهرة. ه r. محمد حسين الحسيني (q . . ب): أساليب مواجهة ضغوط الحياة وعلاقتها بالقلق والاكتئاب لاى عينة من متعاطي المخدرات، رسالة ماجستير، كلية الآداب، جامعة المنصورة. צ r . محمد محمد بيومي ( . . . r): المناخ الأسري وقاية وعلاج "سيكولوجية العلاقات الأسرية"، دار قباء للطباعة والنشر، القاهرة. 


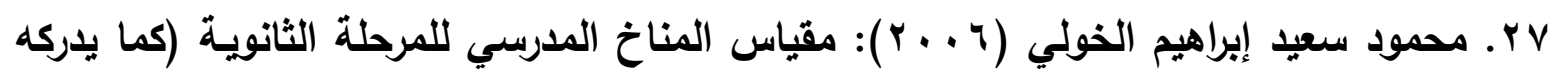
الطلاب)، القاهرة، الأنجلو المصرية.

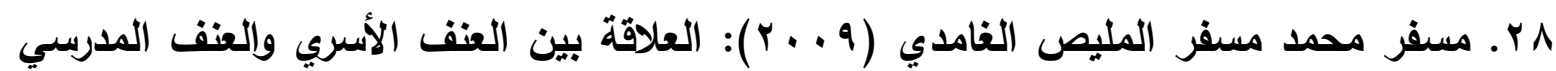

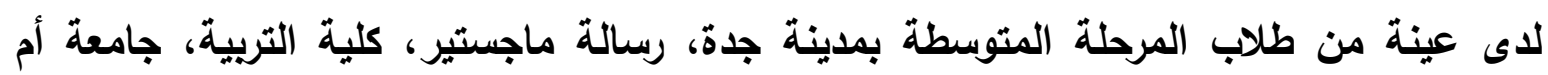
القري، المملكة العربية السعودية.

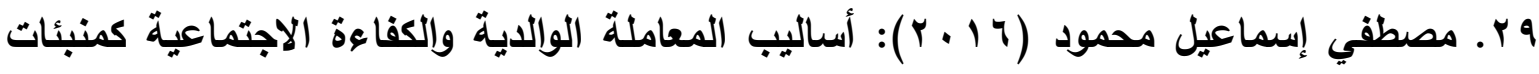

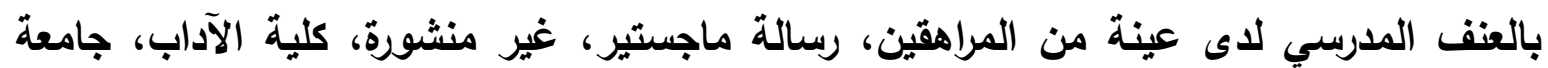
المنيا.

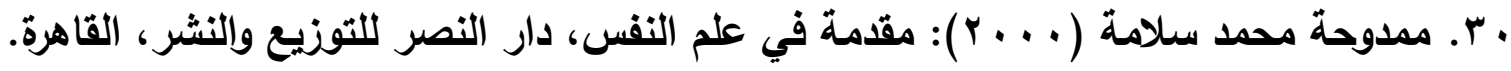

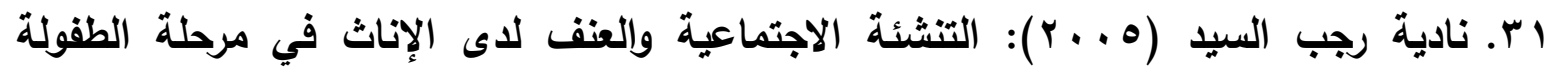

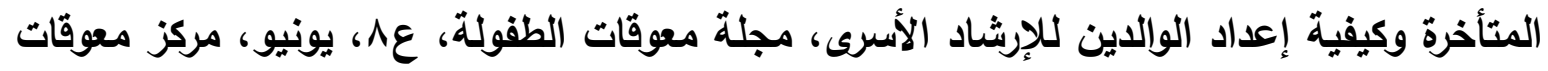
الطفولة، جامعة الأزهر.

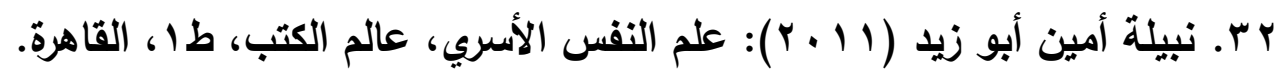

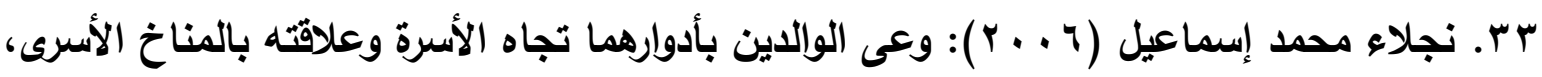
رسالة الاكتوراه ، كلية الاقتصاد المنزلي، جامعة المنوفية.

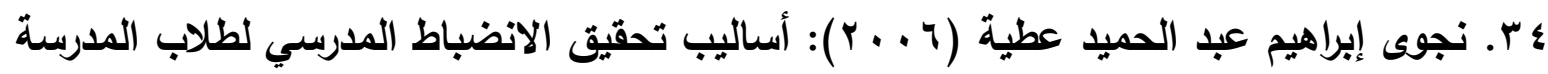
الثانوية "دراسة مقارنة"، رسالة ماجستير غير منشورة، كلية التربية، جامعة الزقازيق.

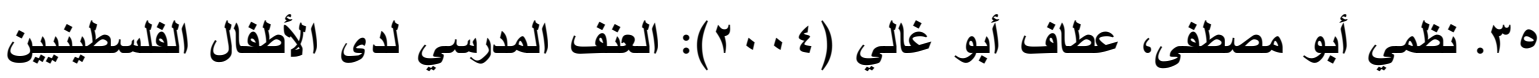

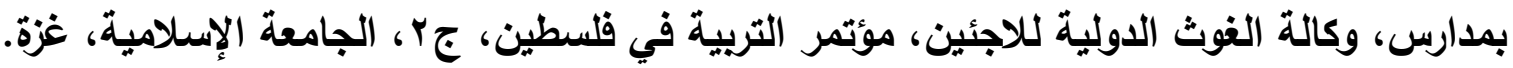

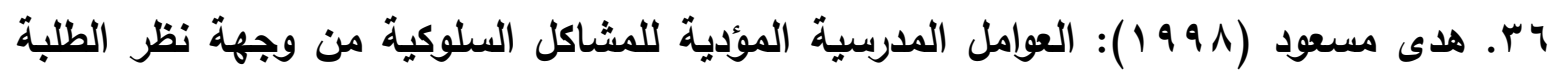

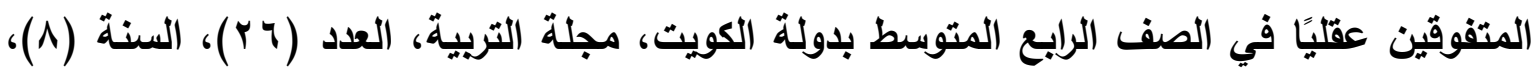

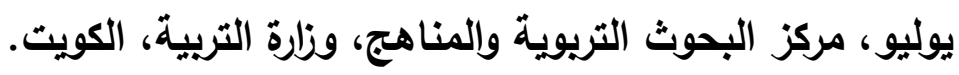

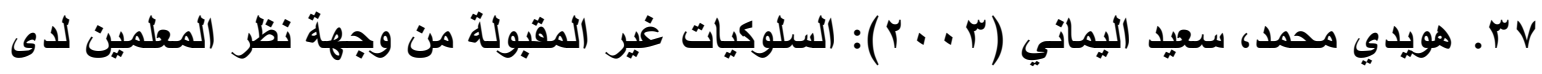
تلاميذ المرحلة الابتدائية بمملكة البحرين، بحث منشور في مجلة العلوم التربوية والنفسية، المجلد (^)، العدد (1)، كلية التربية، جامعة البحرين.

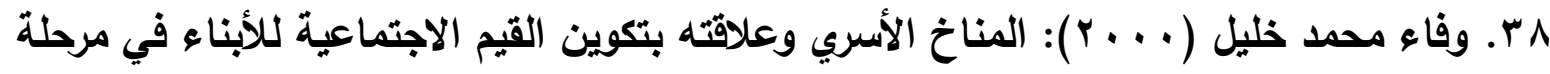

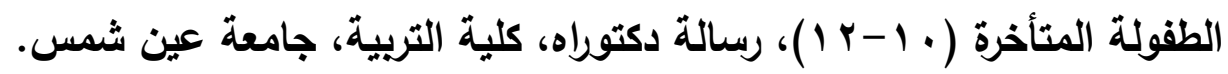

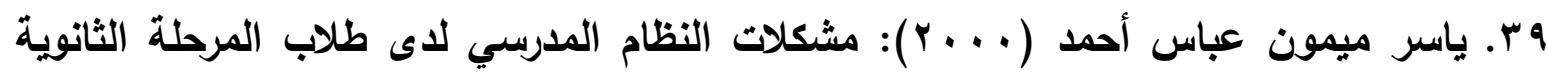
"دراسة ميدانية بمحافظة المنوفية"، رسالة ماجستير غير منشورة، كلية التربية، جامعة المنوفية. 


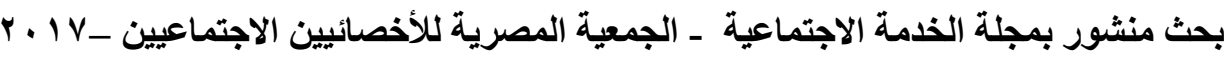

• ـ. يوسف عبد المعطي مصطفي (ب99 1): آراء المعلمين حول بعض قضايا التعليم المصري ومشكلاته، مجلة كلية التربية، المجلد الأول، العدد التاسع، جامعة أسيوط.

41.Agent Memoir (2000):The Relationship Between Elementary School Climate And Student Achievement

42. Curtis Albert Andrews (2000): A Case Study of the types and prevalence of violence at two middle school and high school in the Camden city public school system, ED. D. Wilmington Collage. Dissertation Abstracts International, Vol. 61, No. 3.

43.Douglas Kellner (2000):Globalization and new social Movement. Lessons for critical theory and pedagogy, In: Globalization and Education critical perspective, Nicholas C. Burbules \& Carlos Alberto Torres (Eds.), Routledge, New Yourk.

44.Fields A. Barry (2000): School Discipline: Is There A Crisis In Our Schools? Australian Journal of social Issues, Vol. 35, No. 1, Februray.

45.Gruenert Steve.(2008):School Culture, They Are Not The Same Thing, Principal, March-April.

46.Karin Natvig, et.al (2001): School Related Stress Experience as Risk Factor for bulling behavior, Journal of youth \& Adolescence, Vol. 30, No. 5.

47.Kathien Cotton (2003): School wide and Classroom Discipline, school improvement Series, Close-up, No.9, http//www.nwrel.org/scpd/sirs/5/Cug.html.

48. Magableh, Atef. Yusuf, Hawamdeh \& Basim, Ali (2007): Accountability and discipline in classroom management: case study: Jarash- Jordan College Student Journal,41.

49.Mike Calver, \& Jenny Henderson (1998): Managing Pastoral Care, Gassell Wellington House, London.

50.Modry, Mandell kerri, Gamble, wendy C., Taylor, Angla R. (2007): Family Emotional Climate and Sibling Relationship Quality: Influences on Behavioral Problems and Adaptation in Preschool-Aged Children, Journal of child and Family Studies, 16. 